\title{
Quality of Care in Modern Contraceptive Service Delivery in the Public and Private Sector: A Cross Sectional Study in Indonesia
}

\author{
Ekoriano Mario ${ }^{1} \&$ Ardiana Irma ${ }^{1}$ \\ ${ }^{1}$ National Population and Family Planning Board, Jakarta Timur, Indonesia \\ Correspondence: National Population and Family Planning Board, Jl. Permata No.1 Halimperdanakusuma Jakarta \\ Timur 13650, Indonesia. Tel: 62-812-9171-2229. E-mail: marioekoriano@gmail.com
}

Received: March 27, 2020 Accepted: May 6, 2020 Online Published: May 18, 2020

doi:10.5539/gjhs.v12n7p102 URL: https://doi.org/10.5539/gjhs.v12n7p102

\begin{abstract}
The Government of Indonesia has established a set of program interventions to enhance the quality of family planning services. The program gives preferences to the acceptance of family planning services and the readiness of the supply side. This study is intended to better understand the extent to which the public and private sectors deliver quality family planning services in 4 selected provinces within Indonesia. The six elements of quality of care (Bruce, 1990) were utilized as the study framework. The study confirmed that the mean of all six elements of quality of care are significant (alpha $=0,05$ ) in two out of the four study sites. From the clients' point of view, information on contraceptive choices was the most neglected aspect in the public health facilities, while 'follow up and a continuity mechanism' was most neglected in the private health facilities. The equity index showed a substantial difference in the overall quality of care between the two types of health facilities (public $=4.53$ versus private $=5.34$ ). As far as health providers are concerned, quality of care is still below the optimum standard. Emphasis should be given to formally shape the desired health provider behavior and find a way to create an 'after-sales-service' scheme. The concept of quality goals need to be mindful of program maturity across regions. Periodic monitoring and evaluation is required to ensure more client satisfaction which leading to more sustained use of modern contraceptives.
\end{abstract}

Keywords: quality of care, family planning, modern contraceptive

\section{Introduction}

The law of the Republic of Indonesia number 17/2007 on the 2005-2025 National Long-Term Development Plan (Rencana Pembangunan Jangka Panjang Nasional/RPJPN) states that the ultimate goal of human resources development could be manifested, among others, within population management (Ministry of National Development Planning/National Development Planning Agency, 2005). A large population that is not complemented with high human development index will become a burden rather than an asset for development. In an attempt to offset Indonesia's capacity to improve its human resources, national population growth is expected to reach a replacement level (Total Fertility Rate/TFR $=2.1$ ) by 2025 . This value represents the average number of children a woman would need to have for the population to replace itself and the children who are born survive to childbearing age. Since the Global Statesmen in Population Award was awarded to former President Soeharto by the Population Institute in December 1988, Indonesia has embarked on a long continuous journey of population control that has lasted until today. Between 1971 and 1997 Indonesia successfully reduced its total fertility rate by almost half from on average of 5.61 to 2.78 births per Indonesian woman (Central Bureau of Statistics - BPS et al., 1992; BPS et al., 1995; BPS et al., 1998). However, during the period of 1997-2003 the pace of TFR reduction significantly decreased, resulting in a TFR that has remained stagnant for the last one and a half decades (Figure 1).

Scholars agree that the prevalence of contraceptive use is the most important factor that shapes the fertility level of a society (Bongaarts, 1987). This appears also to be relevant in the context of Indonesia where modern Contraceptive Prevalence Rate (mCPR) is acknowledged to be the best predictor of fertility level. As modern contraceptive uptake declines, the reduction in fertility rate also becomes less promising (Figure 1). The problem is even more acute with the fact that almost one third of contraceptive users discontinue use within the first 12 months (National Population and Family Planning Board - BKKBN et al., 2018). 


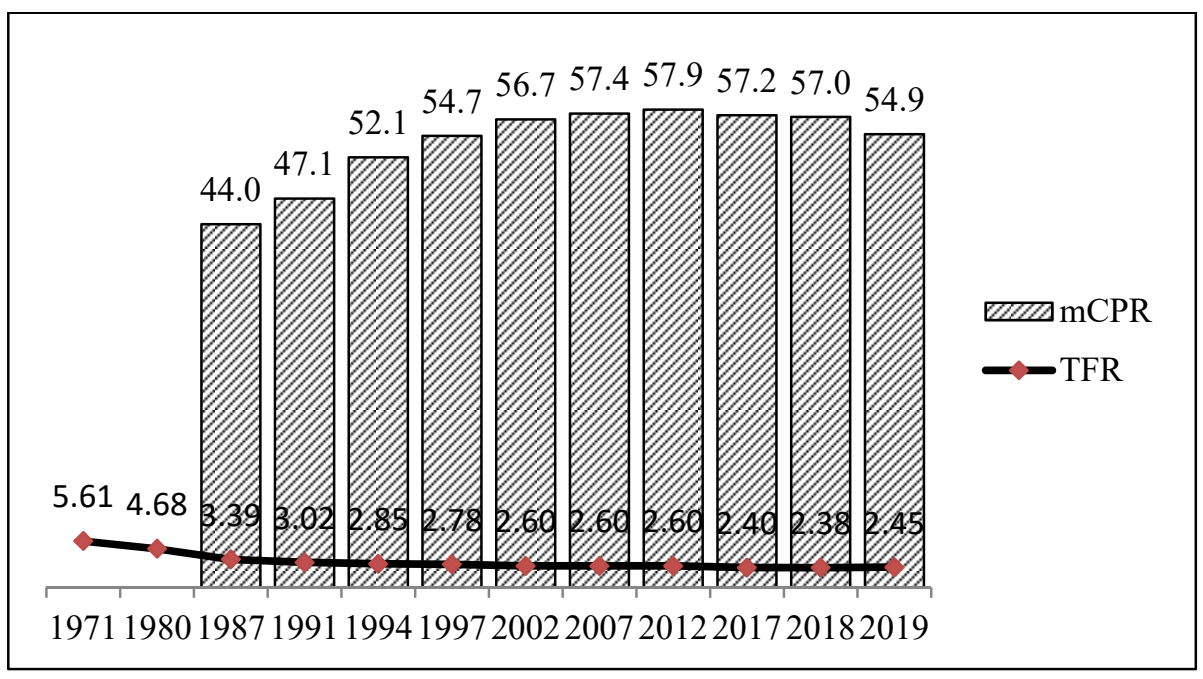

Figure 1. Trends of TFR and $\mathrm{mCPR}$

Source: BPS et al., 1992, BPS et al., 1995, BPS et al., 1998, Statistics Indonesia et al., 2003, Statistics Indonesia et al., 2008, Statistics Indonesia et al., 2013, BKKBN et al., 2018, BKKBN 2019a and BKKBN, 2020

Many discussions have taken place with policymakers and program managers reflecting on the current setback of the family planning program in Indonesia. De-centralization of program implementation following the enactment of Law No. 22/1999 decentralizing to Local Government, as well as the integration of family planning into the National Health Insurance Program (NHIP) launched in 2014, have resulted in a fundamental transformation of family planning services. Decentralization has weakened the capacity of the districts to carry an organized family planning program. It receives less priority from the local governments as it is heavily associated with population control measure (Fathonah \& Ardiana, 2018). The inclusion of family planning in the NHIP has brought changes in the operational mechanism of service delivery mainly in the aspect of the coverage, the benefit, the eligible health facilities, contraceptive distribution and service's payment arrangement (National Population and Family Planning Board, 2014). This ecosystem eventually puts the context in which family planning services are provided both in public and private health facilities.

The National Population and Family Planning Board (Badan Kependudukan dan Keluarga Berencana Nasional/BKKBN), the government body responsible for the population and family planning program (BKKBN, 2017) has incorporated indicators on family planning service quality in its 2015-2019 Strategic Plan. Those indicators are additional contraceptive users and increase in $\mathrm{MCPR}$ in selected disadvantaged areas as a result of increased access to services. These two indicators are programmatically constructed under three indicators including the provision of contraceptives, competent health care providers in providing counseling and performing medical procedure in a health facility and the provision of family planning services in remote areas.

Currently, comprehensive and detailed information on the quality of family planning service in Indonesia is limited. The indicators set above put more emphasis on the realm of supply-side readiness, and to some extent loses client's point of view. The established performance also fails to portray the difference, in the quality of care between public and private health facilities. This study therefore intends to fill the gap in quality of care information and provides insights about the extent the public and private sectors are able to deliver quality service to their clients. The study puts more value in health care provider's viewpoint and client satisfaction towards the service that they receive, and provides room for program managers to gain perception about some aspects of quality services.

\section{Methodology}

\subsection{Conceptual Framework}

The study utilizes the quality of care framework developed by Judith Bruce (Bruce, 1990). It demonstrates the interrelationship between three consecutive compartments program effort, elements in the service received and impact (Figure 2). The framework conceptualizes six elements of quality consisting of choice of methods, information given to users, technical competencies, interpersonal relations, follow up/continuity mechanism, and appropriate constellations of services. 


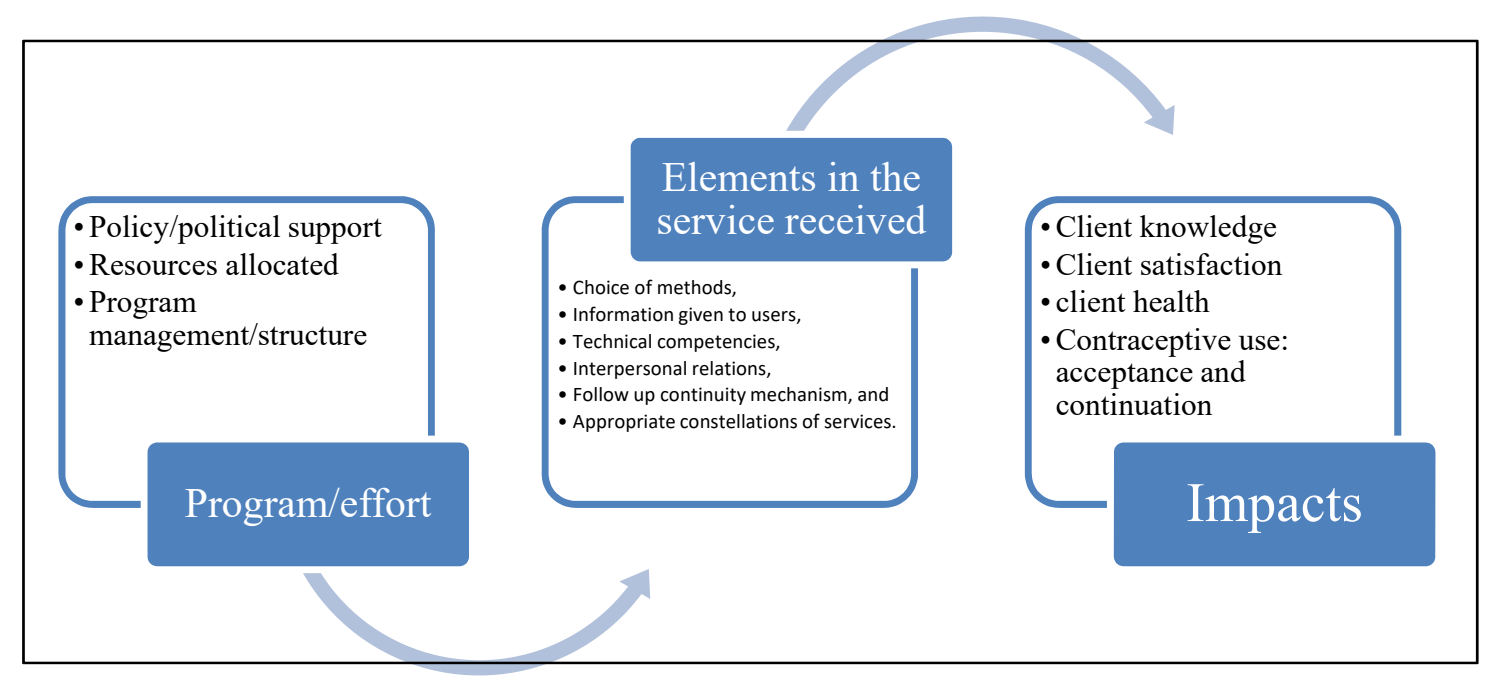

Figure 2. Quality of Care Framework

Source: Bruce, 1990

\subsection{Study Site}

The study took place in four selected provinces East Nusa Tenggara, Maluku, East Java and West Sumatera during November and December 2018 (Figure 3). The selection of those provinces is designed purposively to represent the diversity of Indonesia in terms of socio-economic development (Table 1).

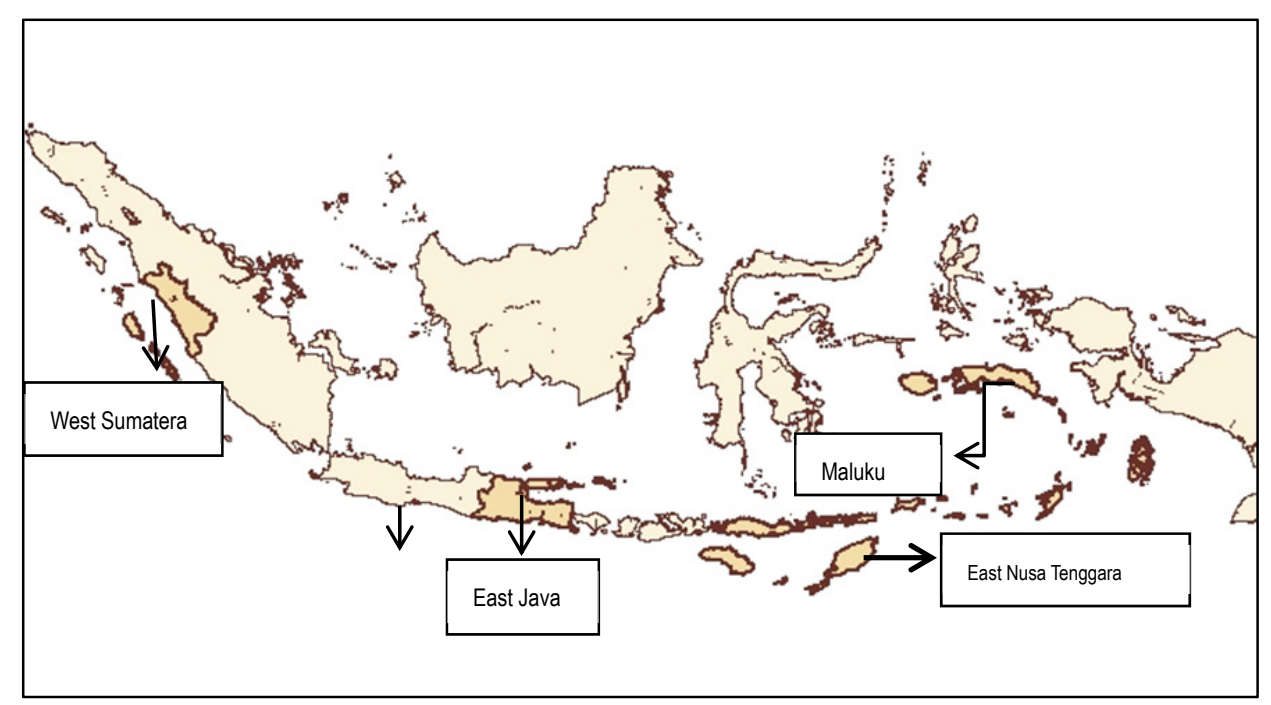

Figure 3. Study Site 
Table 1. Socio-Economic Indicators of the Selected Provinces

\begin{tabular}{|c|c|c|c|c|c|c|}
\hline Socio-economic indicators & Indonesia & $\begin{array}{l}\text { East } \\
\text { Tenggara }\end{array}$ & Nusa & Maluku & East Java & $\begin{array}{l}\text { West } \\
\text { Sumatera }\end{array}$ \\
\hline $\begin{array}{l}\text { Mean Years of Schooling in } \\
\text { Population aged } 15 \text { Years } \\
\text { and above: } 2018\end{array}$ & 8.58 & 7.7 & & 9.78 & 7.93 & 9.10 \\
\hline $\begin{array}{l}\text { Human Development Index } \\
\text { by Province, } 2017\end{array}$ & 70.81 & 63.73 & & 68.19 & 70.27 & 71.24 \\
\hline $\begin{array}{l}\text { Total Monthly Average } \\
\text { Expenditure per Capita } \\
\text { (rupiahs), } 2018\end{array}$ & $1,124,717$ & 704,754 & & 965,837 & $1,218,079$ & $1,148,630$ \\
\hline
\end{tabular}

Source: Statistics Indonesia, 2019.

Note: 1 USD \$ (March, 2018) = Rp.13.890.

\subsection{Sampling Procedure}

The sampling method in this study utilizes non probability sampling with purposive technique. The collected data and information do not represent figures on provincial and national scale. The result is applicable to the sub population under the unit of analysis as proxy measures. It is noteworthy that a sizeable amount of the sample is eligible for appropriate data analysis.

\subsection{Methods}

Study analysis was constructed based on 2 (two) frameworks using a combination of qualitative and quantitative methods. The qualitative method gathered data and information from desk review and in-depth interview of key stakeholders and health care providers. The desk review aimed to explore the policy and strategy for implementing a high-quality family planning program, related targets and the current accomplishments. In-depth interviews were conducted to gain insight on programs implementation relevant to the 34 respondents from the Provincial Family Planning Office (PFPO), Provincial Health Office (PHO), District Family Planning Office (DFPO) and District Health Office (DHO), health care providers are those working in the public and private health facilities which were purposively selected. The inclusion criteria of the selected health facilities are those already registered in the BKKBN networks and sub networks as well as having 30 family planning services at minimum per week for the last month prior to the interview. The in-depth interviews were conducted with 59 and 34 health workers from public and private facilities respectively (see Table 2).

The quantitative method used two different techniques i.e descriptive and inferential analysis. The descriptive analysis was performed through face to face interviews by using a structured questionnaire with clients (see Appendix A). The development of the questionnaire refers to the manual on quick investigation of quality (Measure Evaluation, 2016). The inclusion criteria of clients are married women age 15-49 years old who just received family planning services from the health facility. The services included are switching current method and for new or revisiting acceptors. Women aged under 15 and above 49 years old, having only health consultation and contraceptive removal are defined as the exclusion criteria. Face to face interviews conducted with 278 clients from government facilities and 204 clients accessing private delivery points (see Table 2). The proportion and the sample size were determined by the successful interviews by the time the study had taken place for data collection. Married women were interviewed immediately after receiving health services (exit interview) to prevent any possible recall bias. Inferential analysis was only conducted on clients. Client's standpoint on the quality of care is expressed in the six elements of quality of care. 
Table 2. Unit of Analysis by Source of Service in Four Selected Provinces

\begin{tabular}{|c|c|c|c|c|c|c|c|}
\hline \multirow[b]{3}{*}{ Province } & \multicolumn{6}{|c|}{ Source of Service } & \multirow[b]{3}{*}{$\begin{array}{l}\text { Number of } \\
\text { stakeholders }\end{array}$} \\
\hline & \multicolumn{3}{|l|}{ Public Sector } & \multicolumn{3}{|c|}{ Private Sector } & \\
\hline & $\begin{array}{l}\text { Health } \\
\text { Facility }\end{array}$ & $\begin{array}{l}\text { Number of } \\
\text { Health } \\
\text { Care } \\
\text { Providers }\end{array}$ & $\begin{array}{l}\text { Number of } \\
\text { Married } \\
\text { Women }\end{array}$ & $\begin{array}{l}\text { Health } \\
\text { Facility }\end{array}$ & $\begin{array}{l}\text { Number of } \\
\text { Health } \\
\text { Care } \\
\text { Providers }\end{array}$ & $\begin{array}{l}\text { Number of } \\
\text { Married } \\
\text { Women }\end{array}$ & \\
\hline \multirow{2}{*}{$\begin{array}{l}\text { East Nusa } \\
\text { Tenggara }\end{array}$} & Hospital & 3 & 0 & $\begin{array}{l}\text { Private } \\
\text { Midwife }\end{array}$ & 4 & 14 & \multirow{2}{*}{9} \\
\hline & $\begin{array}{l}\text { Community } \\
\text { Health Center }\end{array}$ & 13 & 106 & Clinic & 3 & 0 & \\
\hline \multirow{2}{*}{ Maluku } & Hospital & 3 & 5 & $\begin{array}{l}\text { Private } \\
\text { Midwife }\end{array}$ & 5 & 62 & \multirow{2}{*}{8} \\
\hline & $\begin{array}{l}\text { Community } \\
\text { Health Center }\end{array}$ & 13 & 55 & Clinic & 5 & 0 & \\
\hline \multirow{3}{*}{ East Java } & Hospital & 2 & 0 & Hospital & 1 & 20 & \multirow{3}{*}{9} \\
\hline & $\begin{array}{l}\text { Community } \\
\text { Health Center }\end{array}$ & 10 & 56 & $\begin{array}{l}\text { Private } \\
\text { Midwife }\end{array}$ & 5 & 29 & \\
\hline & & & & Clinic & 2 & 15 & \\
\hline \multirow{2}{*}{$\begin{array}{l}\text { West } \\
\text { Sumatera }\end{array}$} & Hospital & 6 & 4 & $\begin{array}{l}\text { Private } \\
\text { Midwife }\end{array}$ & 8 & 64 & \multirow{2}{*}{8} \\
\hline & $\begin{array}{l}\text { Community } \\
\text { Health Center }\end{array}$ & 9 & 52 & Clinic & 1 & 0 & \\
\hline \multicolumn{7}{|l|}{$\begin{array}{l}\text { Total } \\
\text { Stakeholde } \\
\text { rs }\end{array}$} & 34 \\
\hline $\begin{array}{l}\text { Total } \\
\text { Health } \\
\text { Care } \\
\text { Providers }\end{array}$ & \multicolumn{3}{|l|}{59} & \multicolumn{3}{|l|}{34} & \\
\hline $\begin{array}{l}\text { Total } \\
\text { married } \\
\text { women }\end{array}$ & 278 & & & 204 & & & \\
\hline
\end{tabular}

The inferential analysis attempts to test the hypothesis of the elements using mean difference and general linear regression model. The mean differences consist of the mean of importance or expectation and mean of consistency or reality. Each of the means were valued using a Likert scale ranging from " 1 " as being very unimportant to " 5 " as being very important for the importance/expectation mean. For the mean of consistency/reality "1" was defined as being very inappropriate and " 5 " was defined as being very appropriate (Table 3 ). The analysis values do not represent the corresponding population in the study areas as they only provide a cross-sectional insight to a given characteristic and time. The selected respondents were not identified through a probability sampling design. 
Table 3. Likert Scale for the Mean of Importance/Expectation and Consistency/Reality

\begin{tabular}{lllc}
\hline Importance/expectation & Scale & Consistency/reality & Scale \\
\hline Very unimportant & 1 & Very inappropriate & 1 \\
Unimportant & 2 & Inappropriate & 2 \\
Important enough & 3 & Appropriate enough & 3 \\
Important & 4 & Appropriate & 4 \\
Very important & 5 & Very appropriate & 5 \\
\hline
\end{tabular}

Statistical method was also employed to calculate a quality-of-care index using a general linear regression model on all independent variables simultaneously [not done as a stepwise procedure] for the six elements of quality of care in the public and private sector as well as overall satisfaction as the dependent variable. Standardized regression [beta] was used as the coefficient explaining the correlation between the six elements of quality of care and overall satisfaction. The study adopted the Brand equity estimation and positioned the six elements of quality of care as attributes. The highest value of each attribute does not necessarily indicate the highest value for equity (WMB \& Associates, 2019).

The coefficients used in this analysis were interpreted as variables and overall satisfaction levels based on the following formulas:

$$
\hat{Y}_{i}=a_{1} X_{1 i}+a_{2} X_{2 i}+a_{3} X_{3 i}+\cdots+a_{k} X_{k i}+e
$$

with $\mathrm{i}$ respectively $=1,2,3, \ldots \mathrm{n}$

Where:

$$
\begin{aligned}
\hat{Y}_{i} & =\text { Dependent Variable } \mathrm{Y} \\
\mathrm{X} & =\text { Independent Variables } \\
\mathrm{k} & =\text { Number of Independent Variables }
\end{aligned}
$$

\subsection{Index}

Table 5 lists the index with each number representing the relative "weight" between the beta coefficient of the six elements and the overall beta coefficient based on the entire response set. The index is the ratio between the beta of each attribute [element] in each health sector [public and private] and the overall beta for that attribute. Each health facility type was weighted using General Linear Regression (see Appendices B, C, \& D). The weight of each element in each sector was compared to the overall weight of each element. For example, interpersonal relationship in the public sector was calculated by dividing the weight of interpersonal relationship with the total weight of the corresponding element in the public sector $(0.15 / 1.13=1.22)$. Only the significant index is applicable for index quantification.

The next step is quantifying the mean of the client's level of satisfaction in the public and private sector and mapping it according to the total index of each sector (see Appendix E).

\subsubsection{Data Management}

For qualitative analysis, in-depth interviews were conducted by the assigned researchers who were divided into two groups in accordance to the chosen provinces. The duration of the data collection as about 1 week. The results of the data and information were put in the interview transcript and matrix analysis.

Quantitative data collection was executed by a team for each province for two weeks. The team consisted of a supervisor and enumerators. They were trained by the researchers for three days to be understand their job descriptions and to be ensure appropriate interview technique, role play interviews and data validation. The supervisor might ask enumerators to re-interview if necessary.

\subsection{Research Permit}

The study received a permit from the Head of Research and Development Department, National Population and Family Planning Board (Badan Kependudukan dan Keluarga Berencana Nasional/BKKBN) Number 3325/I/KU.01.04/H4/2018 dated 29 October 2018 using funding support that has been approved for the 2018 fiscal year. 


\section{Result}

\subsection{Qualitative Analysis}

\subsubsection{Desk Review}

In order to increase mCPR to 61.1 percent and at the same time reduce unmet need by 10.14 per cent in 2018 , the Government of Indonesia had set a target of 965,000 additional contraceptive users and to expand the family planning program coverage by 48 percent in 122 remote areas (BKKBN, 2017). Additional users is defined as the difference between current and previous-year additional users divided by the targeted additional users of the current year. Among the 2018 target, the Government is able to maintain 90 percent of participation in contraceptive use (872,097 contraceptive users) plus expand and intensify access to 89 municipalities (BKKBN, 2019b\& 2019c). This accomplishment is mostly due to the 36,272 high- performing health facilities out of the 53,342 health facilities that are equipped with skilled health care providers to perform health promotion and counseling (BKKBN, 2019d). At the same time, contraceptive provision and availability of at least one doctor or one midwife as competent health care providers in every health facility remains a challenge. Among the 15,798 health facilities in the NHIP's program network, only 68.4 percent have contraceptives stocks and 20.2 percent are staffed with trained providers respectively (BKKBN, 2019e \& 2019f).

\subsubsection{In-Depth Interview}

High-quality family planning service includes an impartial policy that is implemented in all aspects including deployment of competent providers, availability of various contraceptives and essential medical devices, constellation of appropriate health service, surveillance over family planning participation, as well as recording and reporting mechanism in both the public and private sector. In general, each level of administrative bureaucracy, at the provincial and district level, should employ an equal platform of partnership that engages the family planning office, health office and Indonesian Midwives Association (IBI). The Provincial Family Planning Office (PFPO) plays an important role in facilitating skill training on long-acting contraceptive method (intrauterine device (IUD)/implant insertion and removal including insertion of IUD postpartum), procurement and distribution of contraceptive logistics to the District Family Planning Office (DFPO), maintenance of family planning participation and mentoring of DFPO (BKKBN, 2014). In terms of contraceptive device, the PFPO provides 5 (five) commodities i.e. pill, 3-monthly injectable, condom, IUD and two-rod implant. The DFPO is responsible to distribute the contraceptives to all public and registered private health facilities. The PHO and DHO take part in a bigger health system of ensuring the quality of the health facility, as well as ensuring both public and private health facilities receive accreditation (Minister of Health Regulation number 46/2015 on Accreditation of Primary Health Care Facility and Minister of Health Regulation number 34/2017 on Accreditation of Hospital). The Head of Community Health Center and Midwife Coordinator function as a bridge between the directive policy and the necessity of health care providers to deliver the best quality service to clients.

The study shows that all health care providers in the public and private health facilities respect the right of clients to be presented with a wide range of contraceptive choices that suits their reproductive goals. During the process of counseling, it has been a common protocol that health care providers offer clients choices for pregnancy prevention. However, existing choices often appear to be limited due to a variety of factors, from disruption in logistics distribution from the DFPO to health facilities, client's preference mismatch, to other provider-driven and technical issues. Contraceptive stock out, particularly for IUDs and implant, is a common problem faced by public and private health facilities throughout the study site. One obstacle that was captured in West Sumatera was that the DFPO only provides the 3-monthly injectable while most clients favor the monthly injectable. More contraceptive variants are available in private health facilities as they are able to apply an 'out-of-pocket' payment mechanism for commodities that are not supplied by the government. Some public sector health care providers in West Sumatera tend to direct clients toward a particular contraceptive method, as seen from interviews:

“...but we direct them to use the non-hormonal method..." (public sector health care, East Nusa Tenggara).

“...usually we suggest that they use IUD...” (public sector health care provider, East Nusa Tenggara).

“...the most important is IUD because it does not contain hormone..." (public sector health care provider, East Nusa Tenggara).

Midwives who working in public health facilities are often confronted with programmatic challenges that those in the private sector do not experience. Time management is an issue in the face of excessive work load. Midwives are required to perform double tasks as a health care provider in Community Health Center and in village health institutions. They are responsible to coordinate family planning service in Community Health Center and its network facilities and are in charge of ensuring the availability of contraceptives at each service delivery point. 
Midwives also proactively pick up contraceptive supplies from DFPO warehouses, which should actually be delivered by the DFPO. In this regard, midwives said:

"The constraint is that we pick up the contraceptives using our own fund... (laugh) ... because there is no funding for logistics distribution from the DFPO to the community health center. We usually send a request, but we only use a motorcycle for the transportation, because there is no budget for transport" (midwife in a community health center, Maluku).

"We usually pick them up, we make a request to DFPO, the devices will be taken out of the warehouse, then we ourselves carry them here (community health center) ... ... Just say, we bring all contraceptives here, I gave some money to the driver, or I just rode a motorcycle ... " (midwife in a community health center, Maluku).

With regards to contraceptive supply chain, the DFPO is responsible to prevent the stock out of commodities in health facilities. The following comments were recorded:

"Probably the registration card is not updated... so far we think there are 96 health facilities registered in the system. Recently we are piloting an online report system...Ambon city just start the pilot this year and I am involved in the project, but when I opened the data there were only 72 registered health facilities.... Next year when all health facilities are already in the system it would be okay" (DFPO, Ambon, Maluku).

"...contraceptive stock out last year was severe. If there is a stock out, we ask health care providers to direct clients to private midwives. This is done after family planning field workers failed to borrow contraceptive from other community health centers..." (DFPO, East Nusa Tenggara)".

In terms of information given to clients, it is noteworthy that family planning information can be conveyed to the community at two levels at the community level with the assistance of family planning field workers and in a health facility with the assistance of health care providers.

“...first information and education are given by those who are responsible for mobilizing the community to visit a health facility, then the community are counseled at the health facility.... this is mobilized by family planning field workers. If potential users come to health facility without being mobilized, they are immediately counseled by midwives and if they agree, they will receive FP service" (PFPO, Maluku).

All health providers are aware of their duty to provide essential information to clients. Some are equipped with a decision-making job aide 9flip chart to help clients understand the information more easily. Counseling determines whether clients should receive service in a primary health facility, be referred to a hospital or undergo another counseling session. The information provided includes contraceptive choices and possible side effects. Below is a statement from a private midwife:

"... after that eer.. I asked about their intention of coming here. If they want family planning service, which method would they like? There are several types, just choose one ... so we provide service based on their choice... what they want ... after the service, all of them returned home ... after that we set an appointment for them to return for the next service" (a health care provider in a private clinic, Maluku).

A common finding that the study recorded was that contraceptive users who return to public and private health facilities to continue using the contraceptive method receive no further counseling on the chosen method or other possible methods. Health care providers mention that the required information was already given to the clients during the first visit. One health care provider in a community health center and one private midwife said:

"... because the active users, just automatically connect to the previous visit... "....mostly they are repeat clients, so we immediately conduct an examination. Eee ... Does the client bring the small family planning card from the health center? We can see from that card their blood pressure, body weight, and we registered them in the registration book. When registration is complete, a health check-up is carried out immediately and we provide family planning service" (health care provider from a community health center, Maluku).

"...for clients who already use contraception, the information is not so detailed. If the client is new, we have to provide detailed information..." (a midwife from a private clinic, East Nusa Tenggara).

One profound demand that health care providers cite for ensuring quality family planning service is filling the gap in health care providers 'competence. One community health center in East Nusa Tenggara reports that none of their midwives had ever received training on family planning service. In a government hospital in West Sumatera, only 3 of their 14 midwives have had proper training. Opportunities for skill training are scarce so junior untrained midwives mostly receive guidance from more skilled midwives through an 'on-the-job training mechanism. To maintain their accreditation, health facilities in West Sumatera take the initiative to collaborate with the DHO, DFPO and PFPO and periodically organize momentum-based contraceptive services partly to provide mentorship 
opportunities between trained and untrained midwives.

"Do not disregard the implementation of a standard operating procedure, because in the future the accreditation process will be more complex and will be evaluated by a quality assurance team..." (midwife Coordinator in a community health center, West Sumatera).

"Family planning services in a community health center network, IUD and implant services must be performed by trained health workers. We who are trained are requested to coach the others..." (midwife Coordinator in a community health center, West Sumatera).

The situation is somewhat different within in private practice midwives who, in the absence of doctor's supervision, are required by regulation to obtain a certificate of competence for IUD/Implant insertion or removal. Midwives therefore voluntarily attend the training using their own fund. In East Java, 5 of the 6 (six) private midwives interviewed completed the training and are therefore allowed to provide services. In-depth interviews noted that the PFPO and the DFPO regard logistics supply to the private sector as a lower priority than that to public sector. As a result, despite the ability to perform more advanced procedure, private midwives tend to limit contraceptive choices to pill and injectable.

In the realm of interpersonal relation between health care providers and clients, most providers in the public and private health facilities follow the principles of good and effective counseling. They are knowledgeable about their role and are able to effectively communicate with their clients. Even though the family planning program has a target to provide more long-acting and permanent methods, health care providers are encouraged to implement client-focused counseling. As such a program manager will be able to confirm that the chosen method is based on an informed choice which is less likely to result in discontinued use.

“...we are not allowed to coerce clients because different clients mean different medical condition. That is it...we cannot...ee..push someone to use implant even though we aim to increase the use of long-acting reversible methods...health providers should provide service based on client's preference... "(PHO, Maluku).

The parameters used by health care providers with regards to interpersonal relation appear to be a combination of individual provider's competence and economic perspective as expressed by some providers:

"I know they're satisfied if they (red: client) return to our clinic with their friends.... that is my standard... if they do not return to my clinic, I'll be miserable..." (health care provider in a private clinic, Maluku).

“... we have to behave nicely, if we are rude, they will not return for follow up. If we act friendly...they will return to us..." (coordinator of community health center, Maluku).

“...we have to please them, do not let them visit other places ..." (health provider in a public facility, Maluku).

In this regard, privacy remains a problem, particularly in public health facilities as family planning counseling is provided in the same room as maternal and child health care (East Java and Maluku).

Follow up on contraceptive users is implemented through a program that is designed to create a complementary relationship between public and private facilities. The program emphasizes a set of strategies that can prevent user discontinuation by enhancing the capacity of family planning field workers to provide information on contraceptives at the grassroots level, promoting long-acting methods through training and medical device provision, implementing a standard operating procedure with an emphasis on the importance of informed choice and strengthening collaboration for resource mobilization. Provinces employ various innovations to promote continued use of contraceptives. In East Java province the DHO, DFPO and the local community health center took time outside their regular working hours to visit the homes of postpartum mothers and pregnant women. The objective of the home visit is primarily to ensure the women practice exclusive breastfeeding, and do not experience significant side effects from their contraceptive use. The hope is also to help women who are not yet protected to then decide about contraception. This initiative is funded by the health operational fund of the local community health center.

Complementary relationship between public and private health facilities seems to be more directed toward strengthening the private facility's ability to meet client's preference for particular methods and to provide service at a time that is convenient for clients. In the context of appropriate constellation of services, family planning has been well integrated with maternal and child health care as well as with reproductive health service in the public and private sectors. In the public sector the approach is widely known as an integrated program while in private practice, services are integrated as a package of health services that must be provided by midwives. However, women who deliver in a public hospital often face barriers to receiving postpartum family planning service. They would either be requested to return to the hospital 40 days after they are discharged to receive the sterilization 
procedure, or go to a community health center for IUD insertion. It is thought that this is a result of the national health insurance program (NHIP) policy of not covering the cost of sterilization procedure during a cesarean section or an IUD insertion post-placental delivery.

"Now postpartum family planning and delivery is counted as one package. Female sterilization must be separated from delivery care. If they are combined, it will not be paid by the program. If a woman wants IUD post-placental delivery, we usually suggest that she goes to a community health center..." (general practitioner in a public hospital, East Nusa Tenggara).

In East Java, health care providers provide flexible services in a response to client's need. Village-based midwives as part of the community health center's service network provide services in the evening since the majority of their clients are farmers who are free only in the evening.

\subsection{Quantitative Analysis}

\subsubsection{Descriptive Analysis}

Study respondents were largely housewives of various educational level (Figures $4 \& 5$ ). Out of all the respondents, those in East Java appeared to have a better social background. More than half are part of the labor force and attained higher educational levels. At the time of the interview, 80 percent of respondents were active contraceptive users while 20 percent were new users or method switchers. Switchers are defined as women who want to substitute their current contraceptive method with a more suitable one. In terms of respondents' knowledge on a wide range of contraceptive methods, the result for both single and multi-response answers was the same. Regarding top-of-mind, awareness, injectable remains as the method that users remember the most over other available choices (Figures $6 \&$ 7). Male and female sterilization were the least known methods among Indonesian women.

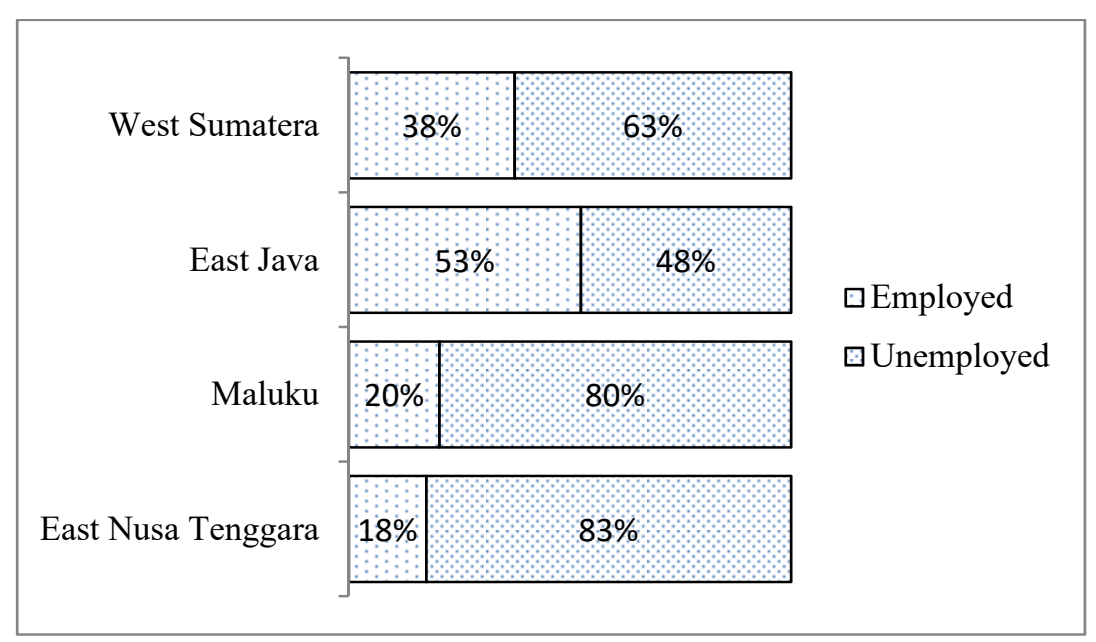

Figure 4. Respondents' Working Status

Source: Processed Data 


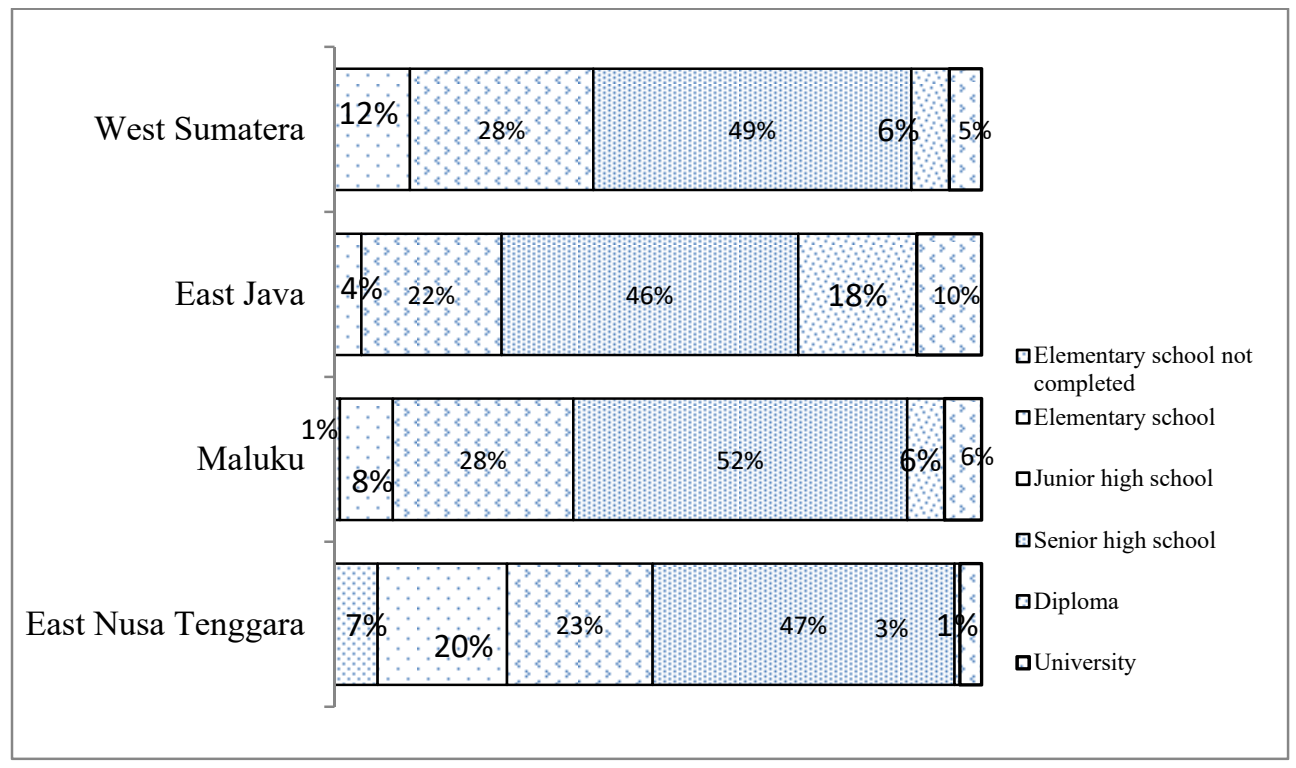

Figure 5. Respondents' Educational Level

Source: Processed Data

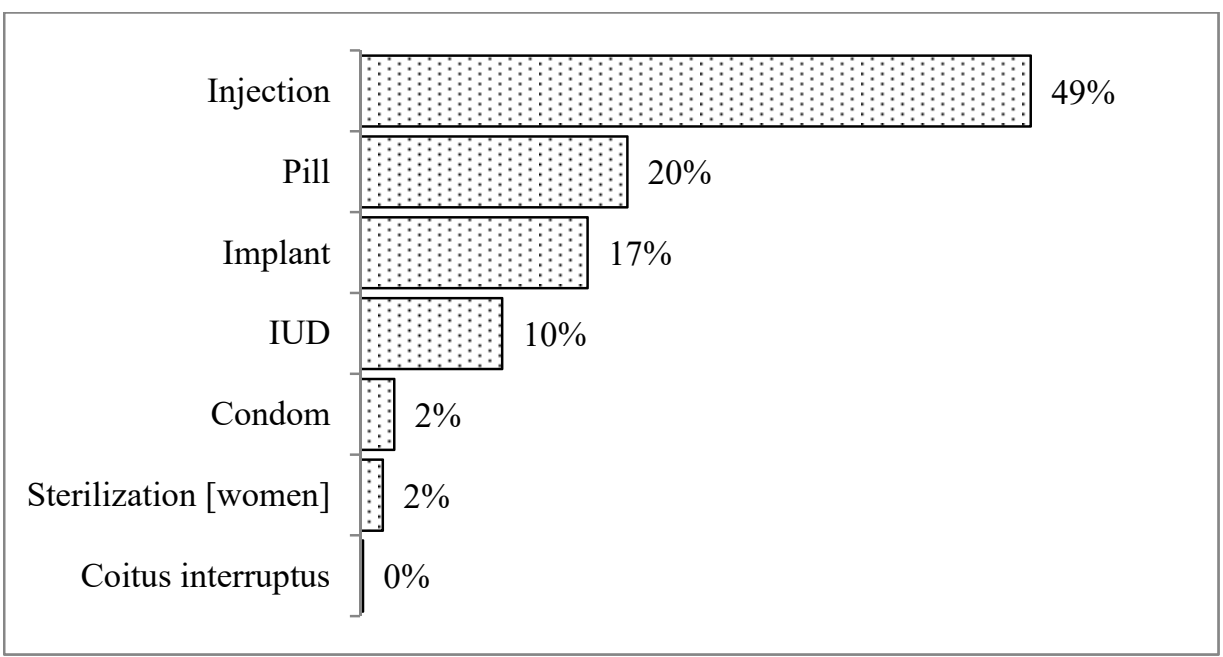

Figure 6. Top-of-Mind Contraceptive Method

Source: Processed Data 


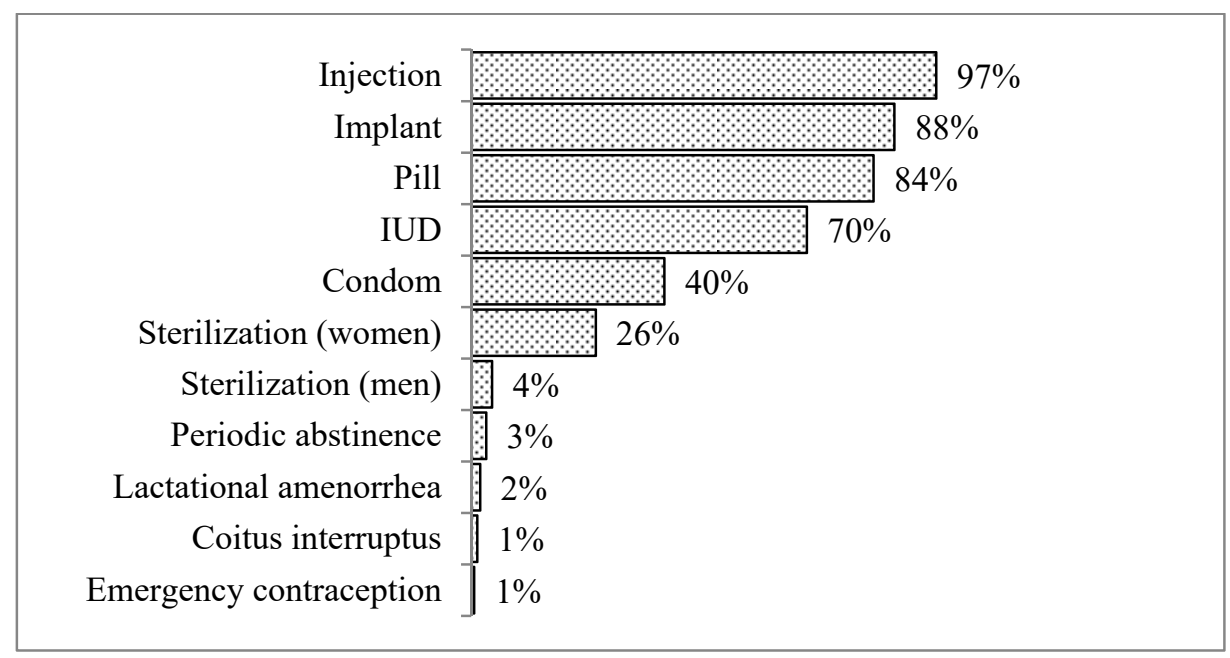

Figure 7. Awareness Contraceptive Method (multi-responses)

Source: Processed Data

\subsubsection{Inferential Analysis}

Generally, respondents in three study provinces perceive family planning servicein the private sector as better than the service provided in the public sector. An exception was in West Sumatera where respondents believed the public sector as more professional than the private sector in delivering quality services in all elements (Table 4). Respondents in East Nusa Tenggara believe public health facilities to be more qualified than private facilities in two elements follow up mechanism and family planning constellation. Family planning constellation was one element that respondents in Maluku believed to be better in the public sector. There remains a gap between services that are expected and services that are actually received for all elements in both public and private facilities. An exception was provider competency in private clinic in East Nusa Tenggara. It is noteworthy that in 3 of the 4 study provinces, with East Java as an exception, appropriate family planning constellation received the poorest feedback from Indonesian mothers (scale $<3$ ).

East Java was the province with the most satisfied respondents in terms of family planning service delivery in all types of facilities. The value of consistency was $\geq 4$. Interestingly, private clinics in East Java were able to exceed the expectation for follow up mechanism and appropriate family planning constellation. The pattern of expectation of clients is noticeable. Government and private health institutions in all four study provinces appear to expect provider's competence as the most important element to be fulfilled, or one that gives more value compared to others. 
Table 4. Significance Test on Quality of Care in Modern Contraceptives Service Delivery

\begin{tabular}{|c|c|c|c|c|c|c|c|c|c|c|c|c|c|}
\hline \multirow{3}{*}{ No } & \multirow{3}{*}{ Quality of Care Element } & \multicolumn{6}{|c|}{ EAST NUSA TENGGARA } & \multicolumn{6}{|c|}{ MALUKU } \\
\hline & & \multicolumn{2}{|c|}{ Government } & \multirow[b]{2}{*}{ Sig } & \multicolumn{2}{|c|}{ Private } & \multirow[b]{2}{*}{ Sig } & \multicolumn{2}{|c|}{ Government } & \multirow[b]{2}{*}{ Sig } & \multicolumn{2}{|c|}{ Private } & \multirow[b]{2}{*}{ Sig } \\
\hline & & $\begin{array}{c}\text { Mean } \\
\text { [NTEREST] }\end{array}$ & $\begin{array}{c}\text { Mean } \\
\text { [CONSISTENCY] }\end{array}$ & & $\begin{array}{c}\text { Mean } \\
\text { [INTEREST] }\end{array}$ & $\begin{array}{c}\text { Mean } \\
\text { [CONSISTENCY }\end{array}$ & & $\begin{array}{c}\text { Mean } \\
\text { [INTEREST] }\end{array}$ & $\begin{array}{c}\text { Mean } \\
\text { CONSISTENCY }\end{array}$ & & $\begin{array}{c}\text { Mean } \\
\text { [INTEREST] }\end{array}$ & $\begin{array}{c}\text { Mean } \\
\text { [CoNsistency] }\end{array}$ & \\
\hline 1 & Choice of methods & 4.05 & 3.47 & 0.00 & 4.07 & 3.86 & 0.19 & 4.60 & 3.67 & 0.00 & 4.60 & 3.89 & 0.00 \\
\hline 2 & Information given to users & 4.21 & 3.82 & 0.00 & 4.14 & 3.86 & 0.0 & 4.60 & 3.95 & 0.00 & 4.71 & 4.15 & \\
\hline 3 & Technical competencies & 4.35 & 4.07 & 0.00 & 4.07 & 4.07 & 1.00 & 4.75 & 4.30 & 0.00 & 4.81 & 4.47 & \\
\hline 4 & Interpersonal relations & 4.18 & 4.00 & 0.00 & 4.00 & 4.07 & 0.34 & 4.78 & 4.38 & 0.00 & 4.82 & 4.40 & 0.00 \\
\hline 5 & Follow up/continuity mechanism & 4.03 & 3.56 & 0.00 & 3.86 & 3.29 & 0.01 & 4.43 & 3.48 & 0.00 & 4.61 & 3.48 & 00 \\
\hline 6 & Approapriate constelations of services & 3.67 & 2.43 & 0.00 & 3.57 & 2.00 & 0.00 & 4.58 & 3.23 & 0.00 & 4.69 & 2.76 & 0.00 \\
\hline \multirow{3}{*}{ No } & \multirow{3}{*}{ Quality of Care Element } & \multicolumn{5}{|c|}{ EAST JAVA } & & \multicolumn{6}{|c|}{ WEST SUMATERA } \\
\hline & & \multicolumn{2}{|c|}{ Government } & & \multicolumn{2}{|c|}{ Private } & & \multicolumn{2}{|c|}{ Government } & & \multicolumn{2}{|c|}{ Private } & \\
\hline & & $\begin{array}{c}\text { Mean } \\
\text { [INTEREST] }\end{array}$ & $\begin{array}{c}\text { Mean } \\
\text { [CONSISTENCY] }\end{array}$ & $\mathrm{Sig}$ & $\begin{array}{c}\text { Mean } \\
\text { [INTEREST }\end{array}$ & $\begin{array}{c}\text { Mean } \\
\text { ICONSISTENCY }\end{array}$ & $\mathrm{Sig}$ & $\begin{array}{c}\text { Mean } \\
\text { [INTEREST }\end{array}$ & $\begin{array}{c}\text { Mean } \\
\text { [CONSISTENCY }\end{array}$ & $\mathrm{Sig}$ & $\begin{array}{c}\text { Mean } \\
\text { [INTEREST }\end{array}$ & $\begin{array}{c}\text { Mean } \\
\text { [CONSISTENCY }\end{array}$ & Sig \\
\hline 1 & Choice of methods & 4.25 & 4.07 & 0.01 & 4.39 & 4.34 & 0.41 & 4.46 & 4.09 & 0.00 & 4.31 & 3.72 & 0.00 \\
\hline 2 & Information given to users & 4.21 & 4.02 & 0.00 & 4.53 & 4.41 & 0.06 & 4.59 & 3.95 & 0.00 & 4.47 & 3.73 & 0.00 \\
\hline 3 & Technical competencies & 4.21 & 4.11 & 0.03 & 4.47 & 4.31 & 0.02 & 4.71 & 4.46 & 0.00 & 4.70 & 4.31 & 0.00 \\
\hline 4 & Interpersonal relations & 4.18 & 4.07 & 0.01 & 4.45 & 4.41 & 0.37 & 4.54 & 4.32 & 0.00 & 4.45 & 4.13 & 0.00 \\
\hline 5 & Follow up/continuity mechanism & 4.14 & 4.00 & 0.04 & 4.34 & 4.38 & 0.57 & 4.54 & 4.20 & 0.00 & 4.39 & 3.97 & 0.00 \\
\hline 6 & Approapriate constelations of services & 4.20 & 4.04 & 0.01 & 4.27 & 4.30 & 0.72 & 4.23 & 3.52 & 0.00 & 3.67 & 2.73 & 0.00 \\
\hline
\end{tabular}

Source: Processed Data [aplha $=0.05]$

According to contraceptive users, the quality of care provided in private health facilities is better compared to that in public health facilities. It is evidenced in the quality-of-care index between these two types of health facilities (4.53 versus 5.34) and the overall client satisfaction score (4.27 versus 4.45 ) (Table 5). The most challenging aspect that public health facilities will need to overcome is the limited choice of methods that they offer to users as they received a value of -0.1 . Public facilities are also more likely to be associated with poor health provider competencies with an index of 0.22 . Despite these, public health facilities are to be commended for having developed a client follow up mechanism that is more effective than that in private hospitals and clinics. Choice of methods and provider's competence were two elements that were superior in the private sector. Private health care providers' competence had an index of 1.78 compared to merely 0.22 for public doctors or midwives. Appropriate constellation of family planning services received a similar reaction in these two types of facilities and has been well documented that the element is regarded irrelevant in the context of quality of care.

Table 5. Quality-of-Care Index in Likert Scale Analyzed as Interval Overall and by Sector [Clients' level of satisfaction by health facility]

\begin{tabular}{lcc}
\hline \multirow{2}{*}{ Elements } & \multicolumn{2}{c}{ Health facility } \\
\cline { 2 - 3 } & Public sector & Private sector \\
\hline Choice of methods & -0.10 & 2.38 \\
Information given to users & 1.13 & 0.64 \\
Technical competence & 0.22 & 1.78 \\
Interpersonal relations (client to health provider) & 1.22 & 0.45 \\
Follow up mechanism/continuity mechanism & 2.06 & 0.09 \\
Appropriate constellation of services & $\mathrm{NS}$ & $\mathrm{NS}$ \\
Index sum /Index Score & 4.53 & 5.34 \\
Overall satisfaction [mean] & 4.27 & 4.45 \\
\hline
\end{tabular}

Source: Processed Data [alpha $=0.1]$.

NS: Not Significant

\section{Discussion}

The family planning program in Indonesia has had a long journey to instill the value of a small, happy and 
prosperous family as a norm and a way of life. This Government's propaganda that was created in 1970s still persists until today, and is still relevant to be broadcast throughout the country. Indonesia succeeded, though far below the expectation, to downsize the ideal family size of 15-to 49-year-old women from 3.1 in 1991 (BPS et al., 1992) to the present 2.7 (BKKBN et al., 2018). More effort will be needed to shape the desirable norms. At the same time these efforts need to be complemented with supply-side readiness. Considering the geographic condition of Indonesia and the uneven distribution of population across eleven thousand inhabited islands, access to family planning service still prove to be a challenge in some areas. Like two sides of a coin, quality of care improvement will need to be accompanied with a growth in service delivery points.

The government has fully considered these two aspects by focusing its attention to the achievement of some related indicators in 2018. Competent providers and distribution of contraceptives are two indicators that have the largest effect on quality of care. Data show that five thousand health facilities do not have an appropriate stock of contraceptive logistics and more health facilities suffer less skilled from incompetent health care providers. Similarly, health care providers gave a lower score to medical training than to contraceptive availability. Challenges in supply chain management might partly rest on the issue of 'formal framework rather than organizational capacity' (Ardiana, Ekoriano, \& Fathonah, 2019). Decentralization that devolves the authority for family planning service delivery to the local government has resulted in a situation that is very different from the previous vertically-arranged program. Transfer of central-level budget to districts/municipalities to finance the transportation of commodities from DFPO's warehouse to health facilities appears inadequate to prevent stock out. Health financing reform with its established system creates more confusion for DFPO in planning resupply quantity. The DHO, DFPO and NHIP's purchaser of health services needs to collaboratively and regularly map and update eligible health facilities as reference for contraceptives provision. Imperfect collaboration, and to some extent, defects in the government internal business process might occur in certain districts/municipalities. In the absence of logistics distribution from DFPO, health facilities can proactively request for contraceptives, but the response from health facilities vary. In the case of Uganda, barriers to family planning quality are more likely due to organizational matters (Mugisha \& Reynolds, 2008).

Quality of care is a concept that has multiple dimensions. Due to data constraint, the study measured quality of care using the Bruce framework, even though there is guidance on quality of care from WHO and human rights standards (WHO, 2017). One limitation of the study is that it is unable to link the social characteristic of respondents, particularly adolescents and potential users, family planning budget, client and provider retention, community trust, crisis setting as well as accountability to the context of a broader quality of care. In a study from Mexico, empiric evidence noted that adolescents or other vulnerable sub-population are more likely to be stigmatized when seeking family planning services (Darney et al., 2016).

The inaccessibility of a wide range of contraceptives compounded by the lack of competent health care providers has ultimately limited the contraceptive choices offered to clients. This creates a circumstance in which clients are most vulnerable to passively receive any available method or otherwise remain unprotected. Proper medical screening and reproductive goal consideration to use contraception are the most sacrificed subjects in this situation, which appears to be more frequently found in the public sector. Since public health facilities are required to fully implement NHIP, they only receive contraceptive logistics from the DFPO. Any disruption in commodities resupply from the PFPO to the DFPO will therefore jeopardize the stock availability and service continuity at service delivery points (BKKBN, 2011). Private health facilities, on the contrary, may implement at least three schemes of family planning financing i.e. through NHIP, private insurance or 'out-of-pocket payment' schemes. Two supply chain frameworks either from the DFPO for NHIP beneficiaries or through a private distribution channel applied for the latter two schemes enable private health facilities to provide a wider choice of methods.

Continuous contraceptive use is an important factor in determining the quality of services given. Once clients are well informed about possible side effect and ways to manage them, sustained use of contraceptive may be more likely. However, specific information about side effects and their management is rarely obtained by Indonesian women who receive family planning services. Side effects were communicated to only 44 per cent of women, and an even lower percentage of women (34 per cent) were taught how to manage the side effects (BKKBN et al., 2018). Indonesian women accessing contraceptive services from private health facilities appear to be lacking from obtaining essential messages. Having no such information, they are vulnerable to believe any myth of misconception and are more likely to end up with discontinuing the method as shown in Nigeria, Kenya and Senegal (Gueye et al., 2015). Other critical view with respect to information provision is the information should be provided as part of a 'client-centered family planning counseling', not a physician-centered consultation (Assaf, Wang \& Mallick, 2017). This latter approach might be associated with service-related factors, and to some extent relates to economic interests to promote a product (Pant \& Pandey, 2018). 
Despite a wider choice of methods in the private sector, the competence of health care providers is not necessarily higher and users do not always receive more information as indicated above. It demonstrates that the choices offered to clients are those that required neither sophisticated medical skill nor further detailed information. The latest Indonesian Demographic and Health Survey (IDHS) (BKKBN et al., 2018) recorded that injectables disproportionately occupy almost two third of modern and traditional methods (68\%) and are mostly accessed through the private sector. It is the top of mind method for clients. For other methods i.e. female sterilization and implant, clients choose to receive the service in a public health facility, which simply indicates that public health facilities are more likely to employ more professional health care providers and have more security in terms of health insurance scheme than private health facilities. Other explainable factors may also be at play such as method-related bias since health providers are likely to work for both sectors at one time. Common positive bias toward injectable and pill, and negative bias toward IUD are commonly found (Solo \& Festin, 2019). Positive bias is a perception that the method is relatively easy to administer and demands more frequent visit, while the reverse counts as negative bias. One driving force of this positive bias is a heavy workload as shown in Iran (Mahan et al., 2008).

The majority of doctors and midwives are not capable to provide family planning services unless they have a certificate of competence through a training that is received after graduating from their school. This is primarily relevant for long-acting contraceptive methods i.e. IUD/implant and sterilization procedure. The Government of Indonesia provided an intensive medical training for health care providers between 2009 and 2014, but the training was not followed by post-training skill retention interventions (Ekoriano, Nasution, Kasmiyati, 2012). The requirement of performing 5 (five) IUD or implant insertion/removal as practice during the first year after the training was implemented in very few provinces. The situation is similar in both the public and the private sectors. The underlying factors include inappropriate inclusion criteria of trainees, unavailability of contraceptives and necessary medical devices, poor demand and to some extent lack of provider's confidence.

Clients accessing family planning services in the public sector have less barrier to build an interpersonal relationship with health care providers compared to their counterpart. This psychological bond acts as affective content allowing two-way communication and question-answer between clients and providers. It is rather unexpected as health providers working in the public health sector carry more burdens as opposed to those in the private sector. The reason might rest on a clearer job description of the health providers as government employee in addition to having a more structured supervision compared to private settings. Good interpersonal relations during family planning counselling promotes sustained contraceptive use and the adoption of highly or moderately effective methods (Dehlendorf et al., 2016). Women receiving high quality of family planning counselling are more likely to initiate the use of modern contraceptive in Uttar Pradesh (Dehingia, 2019).

In contrast with the private sector, the public sector demonstrated more ability to build a mechanism of continuity. Community health centers in particular, are equipped with better resources. The Government of Indonesia gives more weight to capacity strengthening of the community health center, including developing a fund between the Central to Local Government (Ministry of Health, 2015a). Community health centers are required to put more attention to the aspect of health promotion, including family planning, even though the number and distribution of health promotion manpower remains to be a challenge. The Minister of Health Regulation states that community health centers have a network of facilities, sub-community health center and village-based midwives. This financial support and systematic infrastructure attributable to public services position them to better demonstrate follow up mechanism than that of private sectors. It is worth noting as well that continuity also depends on other variables such as accessibility to service delivery point, the method practiced and family support (Thobani et al., 2019).

The constellation of family planning program in Indonesia has experienced a metamorphosis. As a continuation of the Safe Motherhood Initiative, family planning was put as the third pillar in the Making Pregnancy Safer (MPS) Initiative under Indonesia Health 2010 (Bappenas et al., 2013). The strategy was to enable women to prevent unwanted pregnancies through family planning. In the following years, the approach has widened to incorporate family planning into an essential reproductive health package. The package integrated four main programs as a 'one-stop service' i.e. maternal and child health; family planning; sexually transmitted infection prevention and adolescent reproductive health (Ministry of Health, 2015b). Recently family planning was included as one indicator out of the 12 indicators in the Healthy Indonesia Program through a Family Approach (Program Indonesia Sehat melalui Pendekatan Keluarga) (Ministry of Health, 2016). As such the Government expects to maintain the health of Indonesian people using family as a strategic entry point. Various approaches were designed with an aim to deliver better services to the community, but the approach is not yet satisfactory as women might expect far reaching inclusive services. A cross sectional study in Mozambique on the time and place that clients 
consider to be most convenient suggests that family planning constellation still adopts a 'one size fits all' approach. Services are delivered without considering several different approaches that might be required by the community (Galle, 2018).

The study also discovered a large variability in client's perspective toward quality of care's elements across selected provinces. Among the four study provinces, the public and private health facilities in East Java had the highest performance. Data showed that Indonesian women hardly acquire the appropriate constellation of family planning services in both public and private sectors. East Java, again, had a higher-than-expected performance of the private sector. A different picture is seen in the United States where women favor getting family planning services from a community health center due to multiple services that are provided in one site (Susan et al., 2015). The choice is made regardless of the limited choice that the health center offers. This also demonstrates significantly higher use of injectable compared to other health settings. In the early stage of the family planning program implementation (1969-1974) in Indonesia, the program was introduced in 6 (six) selected provinces in Java, including East Java (National Family Planning Coordinating Board/BKKBN, 1982). These provinces were considered to be the most populous provinces that required an earlier birth control policy. East Java was already in an advanced stage of demographic transition compared to other provinces in Java such as Jakarta, Yogyakarta and Bali (Adioetomo, 2018). These provinces already reached fertility at replacement level, accompanied with other gainful indicators such as low infant mortality rate, high Human Development Index as well as an elevated economic growth.

Over all, clients are more satisfied receiving family planning services from the private clinics rather than from public facilities. The two highest values expressed by the women over the services in clinics are availability of various contraceptive choices and the technical competence of the health providers. Systematic review on quality of care in Africa have illustrated common agreement on the consistency of private facilities to maintain contraceptive supplies. But other women in different setting report a likelihood of private facilities to intentionally harm unaware clients by providing expired stock (Tessema et al., 2016). The fraudulent behavior might be based on loose supervision of stock inventory in the clinics. In terms of high appreciation on private health provider competence from Indonesian women, social marketing has partly influenced the desirable perception. In Indonesia it is strongly promoted by the Indonesian Midwives Association as it symbolizes the highest standard care of private midwives (Indonesian Association Midwives, 2015).

One consequence of inadequate quality of care is a high rate of contraceptive discontinuation. The current discontinuation rate in Indonesia is 29 per cent which is dominated by pill users (BKKBN et al., 2018). This can be explained by the method's characteristic where users control the use of contraceptive. Users easily discontinue use when they experience uncomfortable side effects, or other health concerns or desire to become pregnant. Further analysis on demographic variables in Indonesia shows that younger women, women with no living children or just one child, and women who space their pregnancies are more likely to discontinue the use of a particular contraceptive (Samosir, Ayke \& Aninditya, 2019). Reasons for this might be because younger women are less experienced, women with lower parity are less likely to limit births as they have less pressure to avoid an unintended pregnancy in comparison with their counterparts.

\section{Conclusion}

From the clients' perspective, one main finding of the study is that overall private health facilities provide better quality of care than public health facilities. The highest value of private health facilities is their ability to provide information on method choices, while considerable effort is needed to improve the follow up mechanism. The public sector, on the other hand, is mostly appreciated for its continuity program to sustain the participation of contraceptive users. They are however least likely to provide information on other possible contraceptive methods. Emphasis shoud therefore be given to formally shape desired health care providers' behavior and find a way to create an 'after-sales-service' scheme, particularly services provided by the private sector.

The study also confirms that geographic and social differences as well as program maturity influence the quality of care. East Java province as the first province to implement the family planning program and has better social and health outcomes, proves to be most accountable in providing quality services compared to the other three study provinces. Structural issues that were identified demand more collaborative efforts of key stakeholders to continuously improve quality of care. Re-setting the quality platform is necessary to be able to develop a more sensitive policy in an inclusive manner. Program theory could be put into a consideration as a tool to bridge explanations of program interventions and its impacts (Jones \& Rosenberg, 2018). The study also calls for further research and more comprehensive measurement on quality of care to define the contribution of commercial and community-based services in the overall service. 


\section{Acknowledgments}

The authors would like to express a sincere gratitude to National Population and Family Planning Board (BKKBN) especially to Hasto Wardoyo, the Chairman of BKKBN, Siti Fathonah as the Head of Planning Bureau and Zahrofa Hermiwahyoeni as Head of Research on Family Planning and Family Welfare for their valuable guidance. Special thanks to colleagues from Research on Family Planning and Family Welfare Department for their priceless contribution: T.Y Prihyugiarto, Diah Puspitasari, Desy Nuri Fajarningtyas, Sari Kistiana, Resti Pujihasvuty, Mardiana Puspitasari, Sri Lilestina, Margareth Maya, Oktriyanto, Aditya Ramadhony, Hilma Amrullah, Ancha Sitorus, Najib and Viya Yanti Mala. High appreciation is extended to program managers in BKKBN for their fruitful discussion and feedbacks, and to health providers and Indonesian women for allocating their precious time to discuss and to share their expectation for a quality family planning program. The authors also want to demonstrate grateful feeling to Rob Ainslie, senior technical advisor, John Hopkins Center for Communication Program in Indonesia for his precious comments on the paper.

\section{Competing Interests Statement}

The authors declare that there are no competing or potential conflicts of interest.

\section{References}

Adioetomo, S. M. (2018). Closing. In Adioetomo S. M., \& Pardede E. L (Eds.). Memetik bonus demografi: membangun manusia sejak dini [Picking demographic bonus: Building humans early]. 468-469. Depok: PT. Raja Grafindo Persada.

Assaf, S., Wang, W., \& Mallick, L. (2017). Quality of care in family planning services in Senegal and their outcomes. BMC Health Services Research, 17, 346, 1-16. https://doi.org/10.1186/s12913-017-2287-z

Ardiana, I., Ekoriano, M., \& Fathonah, S. (2019). Universal health coverage 2019 in Indonesia: The Integration of family planning services in current functioning health system. Journal of Population and Social Studies [JPSS], 27(3), 247-265. https://doi.org/10.25133/JPSSv27n3.0016

Bappenas, Ministry of Health, Government of Central Java \& the United Nations in Indonesia. (2013). Indonesia accelerating progress towards improving maternal health in Central Java. Jakarta: Bappenas. Retrieved from https://www.id.undp.org/content/dam/indonesia/Project\%20Docs/MDGs/Indonesia\%20MAF\%20-\%20Oct \%2030.pdf

Bongaarts, J. (1987). A framework for analyzing the proximate determinants of fertility. Population and Development Review, 4(1), 105-132. https://www.jstor.org/stable/1972149

Bruce, J. (1990). Fundamental elements of the quality of care: A simple framework. Studies in Family Planning, 21(2), 61-91. https://doi.org/10.2307/1966669

Central Bureau of Statistics, National Family Planning Coordinating Board, Ministry of Health \& Macro International Inc.(1992). Indonesia demographic and health survey 1991. Calverton, Maryland: CBS and Macro International. Retrieved from https://dhsprogram.com/publications/publication-fr18-dhs-final-reports.cfm?cssearch=92236_1

Central Bureau of Statistics, State Ministry of Population/National Family Planning Coordinating Board, Ministry of Health \& Macro International Inc. (1995). Indonesia demographic and health survey 1994. Calverton, Maryland: CBS and Macro International. Retrieved from https://dhsprogram.com/pubs/pdf/FR63/FR63.pdf

Central Bureau of Statistics, State Ministry of Population/National Family Planning Coordinating Board, Ministry of Health \& Macro International Inc. (1998). Indonesia demographic and health survey 1997. Calverton, Maryland, USA: CBS and Macro International. Retrieved from https://dhsprogram.com/pubs/pdf/FR95/FR95.pdf

Blair, G. D., Biani, S. A., Sandra, S. R., Rafael, L., \& Rodriquez, M. I. (2016). Comparison of family planning service quality reported by adolescents and young adult women in Mexico. International Journal of Gynecology and Obstetrics, 134(1), 22-28. https://doi.org/10.1016/j.ijgo.2015.12.003

Dehlendorf, C., Henderson, J. T., Vittinghoff, E., Grumbach, K., Levy, K., Schmittdiel, J., ... Steinauer, J. (2016). Association of the quality of interpersonal care during family planning counseling with contraceptive use. American Journal of Obstetrics \& Gynecology, 215, 78.e1-9. https://doi.org/10.1016/j.ajog.2016.01.173

Dehingia, N., Dixit, A., Averbach, S., Choudhry, V., Dey, A., Chandurkar, D., ... Raj, A. (2019). Family planning counseling and its associations with modern contraceptive use, initiation, and continuation in rural Uttar 
Pradesh, India. Reproductive Health, 16, 178. https://doi.org/10.1186/s12978-019-0844-0

Ekoriano, M., Nasution, S. L., \& Kasmiyati. (2012). Potensi tenaga medis terlatih, klinik pemerintah dan swasta sebagai upaya meningkatkan kesertaan kb mkjp: Fokus iud dan implan [Trained health providers potency between government and private health facilities to increase long term methods particularly for intra uterine device and implants]. Jakarta: BKKBN.

Fathonah, S., \& Ardiana, I. (2018). (Pseudo) Decentralization practices on family planning programs: Strategies for Indonesia to survive for one and half decades. The 20th International Research Conference Proceedings. International Scholarly and Scientific Research \& Innovation, June, 2018, Paris, France.

Galle, A., Vermandere, H., Griffin, S., Melo, M. D., Machaieie, L., Braeckel, D. V., \& Degomme, O. (2018). Quality of care in family planning services in rural Mozambique with a focus on long acting reversible contraceptives: A cross sectional study. BMC Women's Health, 18 (201). https://doi.org/10.1186/s12905-018-0692-z

Gueye, A., Speize, I. S., Corroon, M., \& Okigbo, C. C. (2015). Belief in family planning myths at the individual and community levels and moderns contraceptive use in urban Africa. International Perspectives on Sexual and Reproductive Health, 41(4), 191-199. https://doi.org/10.1363/4119115

Indonesian Midwives Association. (2015). Bidan delima: Pelayanan berkualitas [Delima midwive: Quality of care]. Retrieved from https://ibi.or.id/id/article_view/a20150115001/bidan-delima.html

Jones, D. N., \& Rosenberg, B. D. (2018). Program theory of change. In Frey, BB (Eds). The SAGE Encyclopedia of Educational Research, Measurement, and Evaluation. SAGE Publications, Inc. http://dx.doi.org/10.4135/9781506326139.n548

Mahani, A. S., Omidvari, S., Baradaran, H. R., \& Azin, S. A. (2008). Factors affecting quality of care in family planning clinics: A study from Iran. International Journal for Quality in Health Care, 20(4), 284-290. https://doi.org/10.1093/intqhc/mzn016

Ministry of Health. (2015a). Rencana strategi kementerian kesehatan 2015-2019 [Strategic planning ministry of health 2015-2019]. Jakarta: Ministry of Health. Retrieved from http://www.ppid.depkes.go.id/uploads/img_5cd07f7e6d039.pdf.

Ministry of Health. (2015b). Pedoman pelayanan kesehatan reproduksi terpadu di tingkat pelayanan kesehatan dasar [Manual for integrated reproductive health at primary health care]. Jakarta: Ministry of Health. Retrieved from http://kesga.kemkes.go.id/images/pedoman/BUKU\%20PEDOMAN\%20PKRT.pdf

Ministry of Health. (2016). Pedoman penyelenggaraan program Indonesia sehat dengan pendekatan keluarga [Manual for the provision of Indonesia health program through family approach]. Jakarta. Ministry of Health.

Mugisha, J. F., \& Reynolds, H. (2008). Provider perspectives on barriers to family planning quality in Uganda: A qualitative study. BMJ Sexual \& Reproductive Health, 34(1), 37-41. http://dx.doi.org/10.1783/147118908783332230

Measure Evaluation, (2016). Quick investigation of quality (QIQ): A user's guide for monitoring quality of care in family planning. $\left(2^{\text {nd }}\right.$ ed.) Chapel Hill, North Carolina: MEASURE Evaluation, University of North Carolina. Retrieved from https://www.measureevaluation.org/resources/publications/ms-15-104

Ministry of National Development Planning/National Development Planning Agency. (2005). Visi dan arah pembangunan jangka panjang (PJP) Tahun 2005-2025 [Vision and mission of long-term development plan year 2005-2025]. Retrieved from https://www.bappenas.go.id/files/1814/2057/0437/RPJP_2005-2025.pdf

National Family Planning Coordinating Board. (1982). Informasi dasar program kependudukan keluarga Berencana [Basic information on population and family planning program]. Jakarta: BKKBN.

National Population and Family Planning Board. (2011). Pedoman penerimaan, penyimpanan dan penyaluran alat dan obat kontrasepsi dan non kontrasepsi [Manual for acceptance, storage and distribution of contraceptives and non-contraceptives]. Jakarta: BKKBN.

National Population and Family Planning Board. (2014). Pedoman penyelenggaraan pelayanan keluarga berencana dalam jaminan kesehatan nasional [Manual for the implementation of national health insurance program]. Jakarta: BKKBN.

National Population and Family Planning Board. (2017). Rencana strategis badan kependudukan dan keluarga berencana nasional tahun 2015-2019 [Strategic plan national population and family planning board year 
2015-2019]. Jakarta: BKKBN.

National Population and Family Planning Board, Statistics Indonesia, Ministry of Health \& ICF International. (2018). Indonesia demographic and health survey 2017. Jakarta, Indonesia: BKKBN, BPS, Kemenkes and ICF. Retrieved from https://dhsprogram.com/pubs/pdf/FR342/FR342.pdf

National Population and Family Planning Board. (2019a). Survei kinerja dan akuntabilitas program 2018 [Government performance and accountability program survey 2018]. Jakarta, Indonesia: Center for Research \& Development on Family Planning \& Family Welfare. Retrieved from https://cis.bkkbn.go.id/latbang/?p=15

National Population and Family Planning Board. (2019b). Laporan akuntabilitas kinerja pemerintah 2019: Bidang keluarga berencana dan kesehatan reproduksi [Government performance accountability report 2019: Family planning and reproductive health]. Jakarta: National Population and Family Planning Board.

National Population and Family Planning Board. (2019c). Laporan akuntabilitas kinerja pemerintah 2019: Direktorat wilayah dan sasaran khusus [Government performance accountability report 2019: Specific area and segmentation family planning development directory]. Jakarta: National Population and Family Planning Board.

National Population and Family Planning Board. (2019d). Laporan akuntabilitas kinerja pemerintah 2019: Direktorat kesehatan reproduksi [Government performance accountability report 2019: Reproductive health directory]. Jakarta: National Population and Family Planning Board.

National Population and Family Planning Board. (2019e). Laporan akuntabilitas kinerja pemerintah 2019: Direktorat bina kesertaan KB jalur pemerintah [Government performance accountability report 2019: Family planning participation on government sector directory]. Jakarta: National Population and Family Planning Board.

National Population and Family Planning Board. (2019f). Laporan akuntabilitas kinerja pemerintah 2019: Direktorat bina kesertaan kb jalur swasta [Government performance accountability report 2019: Family planning participation on private sector directory]. Jakarta: National Population and Family Planning Board.

National Population and Family Planning Board. (2020). Survei kinerja dan akuntabilitas program 2019 [Government performance and accountability program survey 2019]. Jakarta: Center for Research \& Development on Family Planning \& Family Welfare.

Pant, P. D., \& Pandey, J. P. (2018). Quality of family planning services delivery and family planning client satisfaction at health facilities in Nepal: Further analysis of the $2015 \mathrm{Nepal}$ health facility survey. DHS Further Analysis Reports No. 113. Rockville, Maryland, USA: ICF. Retrieved from https://dhsprogram.com/pubs/pdf/FA113/FA113.pdf

Samosir, O. B., Kitting, A. S., \& Aninditya, F. (2019). Determinants of contraceptive discontinuation in Indonesia: further analysis of the 2017 demographic and health survey. DHS Working Paper, 159. Rockville, Maryland, USA: ICF. Retrieved from https://dhsprogram.com/pubs/pdf/WP159/WP159.pdf

Statistics Indonesia, National Family Planning Coordinating Board, Ministry of Health \& ORC Macro. (2003). Indonesia demographic and health survey 2002-2003. Calverton, Maryland, USA: BPS and ORC Macro. Retrieved from https://dhsprogram.com/pubs/pdf/FR147/FR147.pdf

Statistics Indonesia, National Family Planning Coordinating Board, Ministry of Health \& Macro International. (2008). Indonesia demographic and health survey 2007. Calverton, Maryland, USA: BPS and Macro International. Retrieved from https://dhsprogram.com/pubs/pdf/FR218/FR218[27August2010].pdf

Statistics Indonesia, National Population and Family Planning Board, Ministry of Health \& ICF International. (2013). Indonesia demographic and health survey 2012. Retrieved from https://dhsprogram.com/pubs/pdf/FR275/FR275.pdf

Solo, J., \& Festin, M. (2019). Provider bias in family planning services: A review of its meaning and manifestations. Global Health: Science and Practice, 7(3), 371-385. https://doi.org/10.9745/GHSP-D-19-00130

Statistics Indonesia. (2019). Perkembangan beberapa indikator utama sosial-ekonomi Indonesia [Trends of the selected socio-economic indicators of Indonesia]. Jakarta, Indonesia: BPS-Statistics Indonesia. Retrieved from

https://www.bps.go.id/publication/2019/08/02/788f274500db4f4c79a09c0f/perkembangan-beberapa-indikat or-utama-sosial-ekonomi-indonesia-mei-2019.html 
Tessema, G. A., Streak, G. J., Mahmood, M. A., \& Laurence, C. O. (2016). Factors determining quality of care in family planning services in Africa: A systematic review of mixed evidence. Plos One, 11(11), e0165627. https://doi.org/10.1371/journal.pone.0165627

Thobani, R., Jessani, S., Azam, I., Reza, S., Sami, N., Rozi, S., ... Saleem, S. (2019). Factors associated with the discontinuation of modern methods of contraception in the low income areas of Sukh Initiative Karachi: A community-based case control study. Plos One, 14(7), 0218952. https://doi.org/10.1371/journal.pone.0218952

Wood, S. F., Beeson, T., Goldberg, D. G., Mead, K. H., Shin, P., Wakil, A. A., ... Rosenbaum, S. (2015). Patient experiences with family planning in community health center. Milken Institute School of Public Health, Geiger Gibson Program in Community Health Policy, Jacobs Institute of Women's Health and RHN Community Health $\quad$ Foundation. Retrieved from https://www.researchgate.net/publication/280530752_Patient_Experiences_With_Family_Planning_in_ Community_Health_Centers.

WHO. (2017). Quality of care in contraceptive information and services, based on human rights standards: $A$ check list for health care providers. Switzerland: WHO. Retrieved from https://www.who.int/reproductivehealth/publications/qoc-contraceptive-services/en/

WMB \& Associates. (2019). Brand equity estimation. Statistical services. Retrieved from http://home.earthlink.net/ statmanz/papers/Brand_Equity_Estimation.pdf 


\section{Appendixes}

Appendix A

Questionnaire

\begin{tabular}{|c|c|c|}
\hline & $\begin{array}{c}\text { Strategic Study Project } \\
\text { QUESTIONNAIRE - Q\&C }\end{array}$ & \\
\hline
\end{tabular}

\section{EAST NUSA TENGGARA}

\section{MALUKU}

3. EAST JAVA

4. WEST SUMATRA

\section{IDENTITY}

Name of interviewer

Name of health facility

Contact number

\section{SECTION 1 : SCREENING}

\section{INTERVIEW WITH SELECTED RESPONDENT}

S1. Did you recently obtain family planning services?

\begin{tabular}{|l|l|l|}
\hline Yes & 1 & CONTINUE TO S2! \\
\hline No & 2 & STOP INTERVIEW! \\
\hline
\end{tabular}

S2. Does your family or close family member work at one of the below institutions or work as one of the below professions?

\begin{tabular}{|c|c|c|}
\hline District Population and Family Planning Office & 1 & \multirow{5}{*}{ STOP INTERVIEW! } \\
\hline Family Planning Field Worker & 2 & \\
\hline Cadre & 3 & \\
\hline Head of family planning sub district & 4 & \\
\hline National Population and Family Planning Board & 5 & \\
\hline None & 6 & CONTINUE INTERVIEW! \\
\hline
\end{tabular}

S3. For the purpose of data grouping, how old are you (mention her/his name)?

Age: ... years old

Date of birth: Day... month....year...

S4. Gender :

Male

Female

S5. Employment of respondent : Are you currently...?

Unemplayed

Employed (Please specify.........) 
S6. Education level: What is the highest degree or level of school you have completed?

Elementary school not completed

$\begin{array}{ll}\text { Elementary school } & 2 \\ \text { Junior high school } & 3 \\ \text { Senior high school } & 4 \\ \text { Diploma } & 5 \\ \text { University } & 6\end{array}$

S7. Resident: Where do you live?

$\begin{array}{ll}\text { Urban } & 1 \\ \text { Rural } & 2\end{array}$

S8. Type of client visit to health facilities : What is the purpose of your current visit?

Revisit

\section{1}

First visit

2

Visit to change method of contraceptive

S9. Place of health facilities: Where did you obtain family planning service?

$\begin{array}{ll}\text { Hospital } & 1 \\ \text { Community health center } & 2 \\ \text { Midwife independent practice } & 3 \\ \text { Private midwife practice } & 4 \\ 24 \text { hours clinic } & 5 \\ \text { Others..............(please specify!) } & 6\end{array}$

\begin{tabular}{|l|l|l|}
\hline I hereby declare that this interview is TRUE AND IN & \\
ACCORDANCE with the INSTRUCTIONS given at the briefing. If I & Signature of & Checked by \\
have violated it, I am willing to pay compensation in accordance with & $\underline{\text { Interviewer: }}$ \\
applicable regulations. & & $\underline{\text { Supervisor: }}$ \\
I HAVE PROMISED MYSELF TO ALWAYS PROVIDE VALID & & \\
AND TRUE DATA, BECAUSE FOR ME TO WORK HONESTLY IS \\
WORSHIP.
\end{tabular}

\section{SECTION 2: AWARENESS}

Q1. According your opinion, what types of contraceptive do you know?

\begin{tabular}{|l|c|l|l|}
\hline TOM (S) & 1 & Female sterilization & 1 \\
\hline Female sterilization & 2 & Male Sterilization & 2 \\
\hline Male Sterilization & 3 & Implant & 3 \\
\hline Implant & 4 & Intra Uterine Device (IUD) & 4 \\
\hline Intra Uterine Device (IUD) & 5 & Condom & 5 \\
\hline Condom & 6 & Lactational Amenorrhea Method (LAM) & 6 \\
\hline Lactational Amenorrhea Method (LAM) & & & \\
\hline
\end{tabular}




\begin{tabular}{|l|c|l|c|}
\hline Periodic abstinence & 7 & Periodic abstinence & 7 \\
\hline Interrupted Intercourse & 8 & Interrupted Intercourse & 8 \\
\hline Emergency contraception & 9 & Emergency contraception & 9 \\
\hline Pill & 10 & Pill & 10 \\
\hline Injection & 11 & Injection & 11 \\
\hline Others (Please specify)......... & 12 & Others (Please specify)......... & 12 \\
\hline
\end{tabular}

Note: S (Single answer), M (Multiple answer)

Q2. What type of contraception are you using now?

Note: Client has just received family planning service!!

\begin{tabular}{|l|c|}
\hline Contraceptive methods & Code \\
\hline Female sterilization & 1 \\
\hline Male Sterilization & 2 \\
\hline Implant & 3 \\
\hline Intra Uterine Device (IUD) & 4 \\
\hline Condom & 5 \\
\hline Lactational Amenorrhea Method (LAM) & 6 \\
\hline Periodic abstinence & 7 \\
\hline Interrupted intercourse & 8 \\
\hline Emergency contraceptive & 9 \\
\hline Pill & 10 \\
\hline Injection & 11 \\
\hline Others (Please specify)......... & 12 \\
\hline
\end{tabular}

Q3. From various service points / contraceptive services, where are the family planning services that you know?

Do not read the answer! The answer can be more than one!

INTERVIEWER !! Mention spontaneously, do not aid!

\begin{tabular}{|l|c|l|l|}
\hline TOM (S) & 1 & Un-Aided (S/M) & 1 \\
\hline Hospital & 2 & Community Health Center & 2 \\
\hline Community Health Center & 3 & Auxiliary Community Health Center & 3 \\
\hline Auxiliary Community Health Center & 4 & Midwife independent practice & 4 \\
\hline Midwife independent practice & 5 & Private midwife practice & 5 \\
\hline Private midwife practice & 6 & Clinic & 6 \\
\hline Clinic & 7 & Pharmacy & 7 \\
\hline Pharmacy & 8 & Sub-district hall & 8 \\
\hline Sub-district hall & 9 & Center of family welfare & 9 \\
\hline Center of family welfare & 10 & Others (please specify).......... & 10 \\
\hline Others (please specify)........ & &
\end{tabular}

Note: S (Single answer), M (Multiple answer) 
Q4. When you come to this health facility with the aim of getting family planning services, how did the staff or administrative officers (other than the provider) treat you?

Very bad

Not good 1

Good enough 2

Good

Very good

Q5. Why did you choose this health facility for obtaining family planning services? Probing!!

Reason:

Q6. Who provided your current contraceptive method?

Doctor

1

Midwife

Family Planning's Field Worker

Others. .(please specify....)

\section{SECTION 3: QUALITY OF CARE}

INTERVIEWER: Tell the respondent, we will talk about family planning services.

Q7. When you come to this health facility for family planning services, did the provider greet you?

Yes

No
1

2

Q8. When you obtained family planning services from the provider, were you informed about the types of contraceptive methods?

Yes

No
1, continue to Q9

2, continue to Q10

Q9. If yes, what explanation did the provider (midwife / doctor) give during family planning services?

If not, do probing! proceed to Q10!

Q10. Were you actively involved in the discussions and did you choose the contraception that is most appropriate to your needs?

Yes

No 
Q11. Did you accept / agree your current contraceptive method being provided by the provider?

Yes

No

Q12. How do you scale health provider's information during family planning counselling between the importance/expectation and the consistency/reality?

\begin{tabular}{|l|c|l|c|}
\hline Importance/expectation & code & Consistency/reality & code \\
\hline Very unimportant & 1 & Very inappropriate & 1 \\
\hline Unimportant & 2 & Inappropriate & 2 \\
\hline Important enough & 3 & Appropriate enough & 3 \\
\hline Important & 4 & Appropriate & 4 \\
\hline Very important & 5 & Very appropriate & 5 \\
\hline
\end{tabular}

Q13. Check Q2, if the respondent chooses code 4, then ask when you received an IUD insertion, did you observe no one other than the provider in the room? If not go directly to Q14

Yes

No

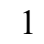

2

Q14. By the time the provider provided family planning service, were you informed that the explanation you gave was confidential?

Yes

1, continue to Q15

No

2, continue to $\mathrm{Q} 16$

Q15. If yes, were you sure the provider would keep the information confidentialt?

Yes

No

Q16. Did the provider ask about the number of children that you want and when do you want to have another child?

$\begin{array}{ll}\text { Yes } & 1 \\ \text { No } & 2\end{array}$

Q17. When you obtained family planning counseling from the provider, did the provider discuss all contraceptive methods that might be most appropriate for you?

Yes

No

Q18. How do you scale health provider's information regarding contraceptive choices that most appropriate for you during family planning counselling between the importance/expectation and the consistency/reality?

\begin{tabular}{|l|c|l|c|}
\hline Importance/expectation & code & Consistency/reality & code \\
\hline Very unimportant & 1 & Very inappropriate & 1 \\
\hline Unimportant & 2 & Inappropriate & 2 \\
\hline Important enough & 3 & Appropriate enough & 3 \\
\hline
\end{tabular}




\begin{tabular}{|l|l|l|l|}
\hline Important & 4 & Appropriate & 4 \\
\hline Very important & 5 & Very appropriate & 5 \\
\hline
\end{tabular}

Q19. Please specify (if any) various contraceptive methods informed by the provider during counselling ?

\begin{tabular}{|l|c|}
\hline Contraceptive methods & code \\
\hline Female sterilization & 1 \\
\hline Male sterilization & 2 \\
\hline Implant & 3 \\
\hline Intra Uterine Device (IUD) & 4 \\
\hline Condom & 5 \\
\hline Lactational Amenorrhea Method (LAM) & 6 \\
\hline Periodic abstinence & 7 \\
\hline Interuppted intercourse & 8 \\
\hline Emergency contraceptive & 9 \\
\hline Pill & 10 \\
\hline Injection & 11 \\
\hline Others (Please specify) $\ldots . . . . .$. & 12 \\
\hline
\end{tabular}

Q20. Did the provider explain that contraception could also prevent HIV/AIDS infection?

Yes

No

Q21. Did the provider inform you about condom double protection?

Yes

No

Q22. When you obtained family planning services, were you treated with full respect and dignity?
Yes
1, continue to Q23
No
2, continue to Q24

Q23. If yes, please specify how the provider treated you?

Q24. How do you scale health provider's attitude in providing contraceptive service between the importance/expectation and the consistency/reality?

\begin{tabular}{|l|c|l|c|}
\hline Importance/expectation & code & Consistency/reality & code \\
\hline Very unimportant & 1 & Very inappropriate & 1 \\
\hline Unimportant & 2 & Inappropriate & 2 \\
\hline Important enough & 3 & Appropriate enough & 3 \\
\hline Important & 4 & Appropriate & 4 \\
\hline
\end{tabular}




\begin{tabular}{|l|l|l|l|}
\hline Very important & 5 & Very appropriate & 5 \\
\hline
\end{tabular}

Q25. When you discussed with the provider about the use of certain contraceptive, did the provider pay attention to your information about the most appropriate contraceptive method for you and your needs?

Yes

No
1

2

Q26. Did you obtain accurate information from the provider, such as how to use contraception, its side effects, and complications from all contraceptive methods?

Yes

No
2

Q27. How do you scale health provider's information on how to use contraceptives, its side effects and complications from all contraceptive methods between the importance/expectation and the consistency/reality?

\begin{tabular}{|l|c|l|c|}
\hline Importance/expectation & code & Consistency/reality & code \\
\hline Very unimportant & 1 & Very inappropriate & 1 \\
\hline Unimportant & 2 & Inappropriate & 2 \\
\hline Important enough & 3 & Appropriate enough & 3 \\
\hline Important & 4 & Appropriate & 4 \\
\hline Very important & 5 & Very appropriate & 5 \\
\hline
\end{tabular}

Q28. Did you obtain information about time to return to the health facility for revisit?

Yes

No

Q29. How do you scale health provider's competency in providing family planning services between the importance/expectation and the consistency/reality?

\begin{tabular}{|l|c|l|c|}
\hline Importance/expectation & code & Consistency/reality & code \\
\hline Very unimportant & 1 & Very inappropriate & 1 \\
\hline Unimportant & 2 & Inappropriate & 2 \\
\hline Important enough & 3 & Appropriate enough & 3 \\
\hline Important & 4 & Appropriate & 4 \\
\hline Very important & 5 & Very appropriate & 5 \\
\hline
\end{tabular}

Q30. Were you informed by the provider to maintain the use of the chosen contraceptive method?

Yes

No
1 , continue to Q31

2, continue to $\mathrm{Q} 32$

Q31. If yes, please specify the information provided by the provider? 
Q32. How do you scale health provider's information on the continuity of the chosen contraceptive method between the importance/expectation and the consistency/reality?

\begin{tabular}{|l|r|l|c|}
\hline Importance/expectation & code & Consistency/reality & code \\
\hline Very unimportant & 1 & Very inappropriate & 1 \\
\hline Unimportant & 2 & Inappropriate & 2 \\
\hline Important enough & 3 & Appropriate enough & 3 \\
\hline Important & 4 & Appropriate & 4 \\
\hline Very important & 5 & Very appropriate & 5 \\
\hline
\end{tabular}

Q33. During the provision of family planning services, did provider check your reproductive organs or ask (if any) complaints related to your reproductive organs?

Explanation: Services can be provided such as screening and diagnosis of possible reproductive tract infections, sexually transmitted infections, or others

Yes

No

Q34. How do you scale health provider's additional services include screening and diagnosis of reproductive tract infections, sexually transmitted infections, or others between the importance/expectation and the consistency/reality?

\begin{tabular}{|l|c|l|c|}
\hline Importance/expectation & code & Consistency/reality & code \\
\hline Very unimportant & 1 & Very inappropriate & 1 \\
\hline Unimportant & 2 & Inappropriate & 2 \\
\hline Important enough & 3 & Appropriate enough & 3 \\
\hline Important & 4 & Appropriate & 4 \\
\hline Very important & 5 & Very appropriate & 5 \\
\hline
\end{tabular}

Q35. How long was family planning counseling provided? ..minutes

Q36. Did it take too long for you to be served in this health facility?

Note: The time is calculated since respondent's registration until she/he obtained family planningservices

Yes

No
1

2

Q37. How long is the waiting time for family planning services?

minutes

Q38. Were you informed by the provider about what you should and should not do following the services?

Yes

No 
Q39. Were you informed by the provider when to re-visit this health facility?

Yes

1

No 2

Q40. How satisfy do you measure the overall family planning services provided by the provider in this health facility?

Very dissatisfied 1

Dissatisfied 2

Quite satisfied 3

Satisfied 4

Very satisfied 5

\section{Signature of the respondent}

(Respondent has been interviewed)

\section{Appendix B}

Overall Parameter Beta

\begin{tabular}{|l|l|l|l|l|}
\hline \multirow{2}{*}{ Variables } & \multirow{2}{*}{ Std. Error } & $\begin{array}{l}\text { Standardized } \\
\text { Coefficients }\end{array}$ & \multirow{\mathrm{t}}{*}{ Sig. } \\
\cline { 3 - 4 } & & Beta & & \\
\hline (Constant) & 0.26 & & 7.29 & 0.00 \\
Choice of methods & 0.04 & 0.09 & 1.74 & 0.08 \\
Information given to users & 0.05 & 0.17 & 3.47 & 0.00 \\
Technical competencies & 0.05 & 0.15 & 3.02 & 0.00 \\
Interpersonal relations & 0.06 & 0.13 & 2.66 & 0.01 \\
Follow up/continuity mechanism & 0.04 & 0.09 & 1.89 & 0.06 \\
Appropriate constellations of services & 0.03 & -0.04 & -0.89 & 0.37 \\
\hline
\end{tabular}

Dependent Variable: Overall, how satisfied are you with family planning services?

Significant at $95 \%$ level 


\section{Appendix C}

Client response to government service

\begin{tabular}{|l|l|l|l|l|}
\hline \multirow{2}{*}{ Variables } & \multirow{2}{*}{ Std. Error } & $\begin{array}{l}\text { Standardized } \\
\text { Coefficients }\end{array}$ & \multirow{2}{*}{ Sig. } \\
\cline { 3 - 5 } & & Beta & 5.43 & 0.00 \\
\hline (Constant) & 0.36 & -0.01 & -0.14 & 0.89 \\
Choice of methods & 0.06 & 0.20 & 3.08 & 0.00 \\
Information given to users & 0.06 & 0.03 & 0.49 & 0.62 \\
Technical competencies & 0.07 & 0.15 & 2.47 & 0.01 \\
Interpersonal relations & 0.08 & 0.18 & 2.81 & 0.01 \\
Follow up/ continuity mechanism & 0.05 & 0.00 & 0.06 & 0.95 \\
Appropriate constellations of services & 0.04 & & & \\
\hline
\end{tabular}

Dependent Variable: Overall, how satisfied are you with family planning services?

Significant at $95 \%$ level.

\section{Appendix D}

Client response to private service

\begin{tabular}{|l|l|l|l|l|}
\hline \multirow{2}{*}{ Variables } & \multirow{2}{*}{ Std. Error } & $\begin{array}{l}\text { Standardized } \\
\text { Coefficients }\end{array}$ & $\mathrm{t}$ & \multirow{2}{*}{ Sig. } \\
\cline { 3 - 5 } & & Beta & 5.26 & 0.00 \\
\hline (Constant) & 0.37 & 0.20 & 2.43 & 0.02 \\
Choice of methods & 0.07 & 0.11 & 1.38 & 0.17 \\
Information given to users & 0.07 & 0.26 & 3.52 & 0.00 \\
Technical competencies & 0.08 & 0.06 & 0.79 & 0.43 \\
Interpersonal relations & 0.08 & 0.01 & 0.11 & 0.91 \\
Follow up continuity mechanism & 0.05 & -0.05 & -0.66 & 0.51 \\
Appropriate constellations of services & 0.05 & &
\end{tabular}

Dependent Variable: Overall, how satisfied are you with family planning services?

Significant at $95 \%$ level 


\section{Appendix E}

Equity, linear model mapping on an overall satisfaction versus total index between government and private sector

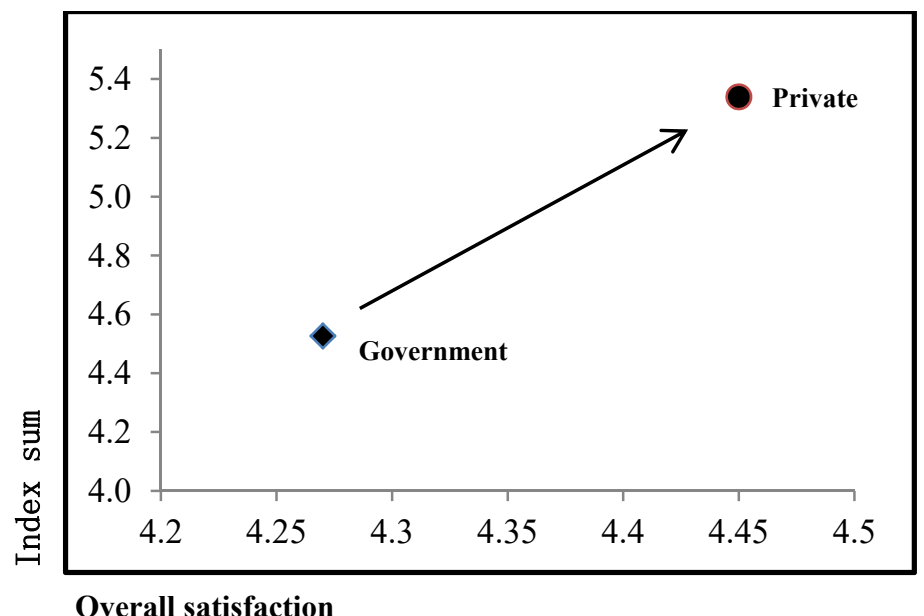

\section{Copyrights}

Copyright for this article is retained by the author(s), with first publication rights granted to the journal.

This is an open-access article distributed under the terms and conditions of the Creative Commons Attribution license (http://creativecommons.org/licenses/by/4.0/). 